\title{
The Gendered Geography of War: Confederate Women as Camp Followers
}

\author{
A Thesis \\ presented to \\ the Faculty of California Polytechnic State University, \\ San Luis Obispo
}

In Partial Fulfillment

of the Requirements for the Degree

Master of Arts in History

By

Rachael Ryen

November 2011 
(C) 2011

Rachael Ryen

ALL RIGHTS RESERVED 


\section{COMMITTEE MEMBERSHIP}

TITLE: The Gendered Geography of War: Confederate Women as Camp Followers

AUTHOR: Rachael Ryen

DATE SUBMITTED: November 2011

COMMITTEE CHAIR: Robert Detweiler, PhD. Professor of History

COMMITTEE MEMBER: Thomas Trice, PhD. Professor of History

COMMITTEE MEMBER: Kathleen Cairns, PhD. Professor of History 


\section{ABSTRACT \\ The Gendered Geography of War: Confederate Women as Camp Followers}

The American Civil War is often framed as exclusively masculine, consisting of soldiers, god-like generals, and battle; a sphere where women simply did not enter or coexist. This perception is largely due to the mobilization of approximately six million men, coupled with the Victorian era which did not permit women to engage in the public sphere. Women are given their place however, but it is more narrowly defined as home front assistance. Even as women transitioned from passive receivers to active participants, their efforts rarely defied gender norms. This thesis looks at Confederate female camp followers who appeared to defy societal conventions by entering the male dominated camps and blurred the lines between men and women's proper spheres. While camp followers could be expanded to include women of the lower class, including black women, laborers, slaves and prostitutes, only middle and upper class white women are analyzed because they were the ones required to maintain respectability. More specifically, I analyze unmarried women, female soldiers, bereaved women and nurses. Barbara Welter articulated and labeled the concept of public versus private spheres, plus the attributes necessary to achieve respectability as the Cult of True Womanhood. The Cult of True Womanhood demanded that women be pious, pure, and submissive within the domestic sphere. It is with this foundation that the camp followers can be analyzed. Their actions appeared to break with the Cult of True Womanhood, but when they explained in memoirs, newspaper accounts, and journals why they entered the camps, they framed their responses in a way that allowed them to appear to conform to the cult.

Key words: camp followers, Confederacy, Confederate women, the Cult of True Womanhood, Civil War, female soldiers, nurses, death, suffrage 


\section{ACKNOWLEDGEMENTS}

I would like to extend a sincere thanks to the History Department, under whose tutelage I was pushed to succeed and expect a level of expertise I never thought previously possible. I would also like to personally thank Dr. Trice for accepting me as a graduate student and seeing potential in me even when I did not.

Dr. Cairns, who acted as a committee member, was instrumental in sparking my passion for gender studies back in my undergraduate years. It was because of her classes and the groundwork she laid that I chose to focus my thesis on Confederate women. Thank you to Dr. Detweiler for helping me focus the scope of my writing. Your feedback was instrumental in pushing me to improve and rewrite, then rewrite again. Your seminars on the Civil War also reignited my love for Southern history, leading me towards this thesis work.

During my graduate studies there were many professors who changed the way I viewed the world and its history, so a big thank you to Dr. Orth, Dr. Hopper, Dr. Murphy and Dr. Hiltpold.

And finally, I would like to thank my family; my mom Cindy, dad Grady and husband Dustin. Their unwavering support was what propelled me along on this arduous journey and inspired in me a confidence that I could truly be an Historian. Thank you. 


\section{TABLE OF CONTENTS}

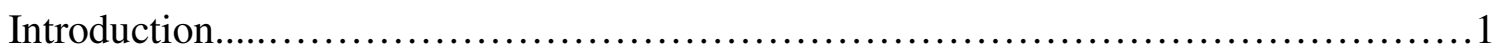

Chapter 1: Unmarried Women in Camp.........................................18

Chapter 2: Female Soldiers in Camp.........................................40



Chapter 4: Nurses in the Camps and Hospitals.....................................82

Conclusion..............................................................99

Bibliography........................................................... 112 


\section{INTRODUCTION}

As General Hooker's division fought along the banks of the Potomac in the spring of 1862, a New York Times correspondent followed the regiment to record the experiences of camp life and the campaign that season. The area of the Potomac, between Virginia and Maryland, was highly contested ground because Shipping Point provided direct access to Richmond. Early in the war Northerners commonly believed that Richmond could be seized quickly, thus precluding the necessity of a protracted war. By 1862, the reality of the war had sunk in, but the hope to take Richmond never abated. On

April $16^{\text {th }}$ the correspondent reported a story that was likely read throughout the country:

The soldiers of Hooker's Division are forbidden to go over to the Virginia side, small parties having gone over recently in boats, and been captured by the enemy...Twenty-one of our soldiers have been taken prisoner by the rebels since the evacuation of the batteries... Assistant Secretary of War Fox, with a party of ladies and gentleman (emphasis mine), visited Shipping Point on Saturday last. They came down in the steamer King Phillip, small pieces of iron and wood belonging to the burnt rebel steamer, George Page, were taken away by their party as relics.

The incident was recorded because it contained a notable figure, but it addresses a larger issue, that the presence of women in camp, or on a battle field, was not unusual. Unfortunately, no additional details about the women were provided, how they were related to the men or whether their party was on a personal or military venture. These details are lost to history, but since it was unlikely that these women were prostitutes or black women, the story indicates that 'respectable' women were accepted within the camp as well. In fact, women had long been a facet of camp life, particularly during the 
Revolutionary War, when necessity prompted them to follow their husbands. ${ }^{1}$ Camps became makeshif homes, where women provided cooking, cleaning, companionship, medical services, and so on to their husbands and fellow soldiers. The Revolutionary War became a collective effort between men and women to the extent that Washington and British officers were forced to enact policy dealing with women's effect on troop movements and resources.

The Civil War was a significant departure from past wars because it mobilized men on an unprecedented scale, laying the foundation for a male dominated sphere. The mobilization of nine percent of the population, or approximately three million men, meant that many aspects of military duty were regulated and institutionalized, leaving little room for women. ${ }^{2}$ Unlike the Revolutionary War which made women a part of the military complex, the Civil War was cast as an exclusively masculine war. ${ }^{3}$ Women's contributions were highly valued, but placed in a framework of secondary homefront assistance that reflected their natural roles as wives and mothers. ${ }^{4}$ Nineteenth century constructs of women's domestic sphere made it important that their efforts remain on the home front, amongst family and friends, in an effort to maintain traditional gender roles.

The idea of nineteenth century gender roles was labeled "The Cult of True Womanhood," by Barbara Welter in 1966. Welter described the cult as a social policy of separate spheres where women were expected to be pious, pure, submissive and domestic in order to be accepted by society, or as a "true women." Further, women were relegated

\footnotetext{
${ }^{1}$ Holly A Mayer, Belonging to the Army: Camp Followers and Community during the American Revolution (Columbia: University of South Carolina Press, 1999), 8-14.

2 James McPherson, The Illustrated Battle Cry of Freedom (Oxford: Oxford University Press, 2003), 487.

${ }^{3}$ Mayer, Belonging to the Army, 1-30.

${ }^{4}$ See Frank Moore, Women of the War: their Heroism and Self-Sacrifice (Hartford: S.S. Scranton \& Co., 1866) for a primary source that is interpreted as a way for men to place women back within the confines of domesticity, and Elizabeth Leonard, Yankee Women: Gender Battles in the Civil War (New York: W.W. Norton, 1995).
} 
to the private sphere, their homes, while men existed in the political, corrupted, public sphere. ${ }^{5}$ Even though some women grappled with the perfection that was demanded of them, most middle and upper class white women identified with and embraced the concept. In the South, where social and economic hierarchies were stridently reinforced, Southern women generally conformed to these expectations. When the Civil War broke out, Southern women were initially hesitant to enter the public sphere in order to provide the goods, services and foodstuffs that were required for the Confederacy's success, in fear that it would tarnish their respectability. Southern women were especially slow to join the emerging women's suffrage movement, seeing it as an extension of Northern industrialism. The South was still largely agrarian on the eve of the Civil War, so most women did not come from developed cities that naturally fostered independence, but they eventually expanded the concept of true womanhood to address the demands of war.

The Cult of True Womanhood has been debated by numerous historians since Welters articulated the concept in the 1960s. Many historians have successfully expanded on the idea, but its core principle has remained steadfast. For example, John Sacher argued in his article, “The Ladies are Moving Everywhere": Louisiana Women and Antebellum Politics," that within the Southern Whig Party, women engaged in unprecedented level of political activism. Sacher argues that Whig women were intrinsic to the political process and routinely demonstrated at rallies, going so far as to speak at Whig functions. ${ }^{6}$ However, Sacher concedes that the Democratic Party was not nearly as inclusive and that the antebellum period was an era of inconsistency and mixed messages.

\footnotetext{
5 Barbara Welter, “The Cult of True Womanhood 1820-1860,” American Quarterly 18 (1966): $152,174$. ${ }^{6}$ John Sacher, "The Ladies are Moving Everywhere": Louisiana Women and Antebellum Politics," Louisiana History: the Journal of the Louisiana Historical Association 42 (2001): 441-447, Elizabeth Varon, "Tippecanoe and the Ladies, Too: White Women and Antebellum Politics in Virginia," Journal of American History 82 (1995): 494-521.
} 
Many Louisiana men were still adamant that woman's role was one of Republican Motherhood, where they were responsible for raising civically minded male children who would grow up to partake in partisan politics, but to not engage themselves. Newspapers also sent mixed messages to their female readers, stating that their involvement in politics was "supremely ridiculous," then calling for women's help at party conventions. Elizabeth Varon supports this argument in "Tippecanoe and the Ladies, Too: White Women and Antebellum Politics in Virginia," arguing that Southern Whigs utilized women's influence more than Democrats, but then admits that women were assigned to the role of moral authority within the party and at rallies, a traditional function of women under the Cult of True Womanhood. ${ }^{8}$

Another author, Harriette Andreadis, writes about the Cult of True Womanhood's effect on frontier women during the nineteenth century in "True Womanhood Revisited: Women's Private Writing in Nineteenth-Century Texas," noting that women used their diaries to lament the disparity between their public and private selves. The women examined often recorded examples of how their identities were continuous with wifehood and motherhood, and only after marriage did they feel fulfilled. ${ }^{9}$ Even on the frontier, which is thought to have provided significant levels of autonomy, women still adhered to traditional gender roles.

The evolving discourse on women's role in the political sphere divided women in many ways. The majority of women remained on the home front and perpetuated traditional roles, but camp followers astutely utilized the loosening restrictions to justify

\footnotetext{
${ }^{7}$ Sacher, "The Ladies are Moving Everywhere," 451.

${ }^{8}$ Varon, "White Women and Antebellum Politics," 495.

${ }^{9}$ Harriette Andreadis, "True Womanhood Revisited: Women's Private writing in Nineteenth-Century Texas," Journal of the Southwest 2 (1989): 185.
} 
their decision to enter camps, simultaneously breaking with gender roles but also appearing to conform to them. In the South, where social hierarchies were more keenly felt, Southern women particularly held onto traditional antebellum ideas of women's natural roles and tied their respectability to their ability to remain in the private sphere. Their respectability had to be earned, and men only placed the women on a pedestal who embodied those ideals. However, the needs of the Confederacy mandated that women reassess their attachment to the private sphere, leaving Southern women to walk a very fine line between tradition and necessity. Even though women took on greater public responsibilities and engaged in politics on the eve of the Civil War, they would still remain disenfranchised for another sixty years.

Gender roles were difficult to adhere to in the camps because they often resembled taverns and brothels. Theophilus Perry described his first days at camp in a letter home to his wife Harriet, indicating that camp life epitomized the concept of a public and corrupted male sphere. On Monday, July 14, 1862 Theophilus wrote that he and a few other soldiers were led by their chaplin into town to retrieve wayward men, recalling, "I had to go to some places, a gentlemen ought never to be caught at, and take them out of the presence of their amours." He went on to explain that while he was in charge, some men returned to camp drunk, a serious offense but certainly not uncommon. The physical conditions of the camp were harsh as well, dust covered everything and Theophilus noted that he took extreme measures to remain clean. ${ }^{10}$ Another soldier, Louis Leon, recorded a few of the hardships and pleasures of camp in his diary, writing on June 23, 1862, "Moved our camp two miles up the road toward Richmond. It is a very bad

\footnotetext{
${ }^{10}$ Theophilus Perry and Harriet Perry, Widows by the Thousand: The Civil War Letters of Theophilus and Harriet Perry 1862-1864, ed. M. Jane Johansson (Fayetteville: University of Arkansas Press, 2000), 3-5.
} 
camp - low ground and muddy. But there is a factory here, and plenty of girls to make up for the damp ground." When shown to his tent Leon recorded his astonishment, writing "We reported to Captain White, and he showed us to our hut. We were surprised to find it without a floor, roof half off and 'holey' all over." Necessities, as well as accustomed goods and luxuries, were hard to come by, particularly as the war drug on. The lack of refinements forced Duren Kelley to write his wife Emma that he feared he would return a "hard boy."11

Camp life hardened many men because it was a monotonous, yet rough existence that was primarily comprised of marching, drilling and manual labor. To make conditions worse, the camps were rife with disease stemming from overcrowding, exposure to foreign diseases, bacterial infections from wounds, and sexual encounters with prostitutes. ${ }^{12}$ Soldiers routinely engaged in illicit sexual activity as a response to the monotony, accessibility of prostitutes, and a lack of familial oversight. Prostitution ran rampant to the point that one in eleven Union soldiers was infected with venereal disease. Confederate soldiers likely faced similar figures, but due to poor records there are no specific statistics. ${ }^{13}$ Drunkenness was also a common occurrence as men drank in local taverns and appropriated liquor from camp surgeons. ${ }^{14}$ The 'rough and tumble' nature of camp was perceived as a natural consequence of high concentrations of men from every socioeconomic background living within a restricted space. The perception of a corrupted male sphere left little room for respectable women to gain access to this population of

\footnotetext{
${ }^{11}$ Duren F. Kelley, The War Letters of Duren F. Kelley 1862-1865, ed. Richard S. Offenberg and Robert Rue Parsonage (New York: Pagent Press, 1967), 20.

${ }^{12}$ James McPherson, Battle Cry of Freedom: the Civil War Era (New York: Oxford University Press, 1988), 487.

${ }_{13}^{13}$ Judith E. Harper, Women During the Civil War: an Encyclopedia (New York: Routledge, 2007), 314.

${ }^{14}$ John O. Casler, Four Years in the Stonewall Brigade (Dayton: Morningside Bookshop, 1971), 55-56, 99.
} 
men, but they fashioned excuses and modes of behavior that allowed them to enter nonetheless.

The camps were not traditional cities or townships, but separate and distinct spheres defined by their populations and purpose. They often had many of the same features of towns, such as churches, general stores and housing, but there was a distinction imposed on the camp that did not characterize a civilian town. An intrinsic difference was its function as a military body heavily regulated by, and dependent upon the government. There is no doubt that civilian towns and camps often interacted and overlapped, but when they did blend, the camp assumed autonomy and imposed martial law. Additionally, the camp population was almost exclusively male and their purpose was not to expand via birth rates and to produce a tax base, but to be temporary structures that fought for the interests of their commanding officer. Under the military complex the camp sphere extended into military hospitals and onto the battlefield. These two areas mirrored the camp because they were regulated by the military and encompassed large concentrations of troops, essentially comprising three sections of one entity. The walls of the camp were permeable, allowing women to enter, but they were cognizant of the shift in spheres that resulted in a shift in social expectations.

All of the women in camp were interconnected through a social hierarchy. The concept of a fluid space rests on an understanding of why women entered the camps and how women on the bottom challenged those on top. Prostitution was the most significant threat because respectable women did not want to be mistaken for sex workers, or appear to be engaging in sexual activity while in the camps. Prostitutes were black and white, slave and free, and many utilized the war as a moneymaking venture without regard for 
loyalties. The Civil War produced unique circumstance where men were significantly more accessible to prostitutes, creating a boon in the industry. Prostitution ran rampant and became a significant health threat for the troops. In response, Lieutenant Colonel George Spalding legalized prostitution for the first time in US history, but required that all prostitutes receive regular check-ups in order to decrease the number of women working with a venereal disease, a policy that was highly successful. ${ }^{15}$ The topic of prostitution during the Civil War is only recently gaining proper attention, primarily because it contradicts romanticized notions of an asexual, Victorian-era soldiering force. $^{16}$

The second group of women on the bottom rung were black women, and they entered the camps in a number of capacities. They acted as laborers in 'colored' Union regiments, providing services such as cooking, cleaning, mending clothes, and so on to the white officers. ${ }^{17}$ Susie King Taylor, wife of a black soldier, recalled in her memoirs that black women commonly nursed fellow soldiers and acted as surrogate mothers. She also lamented that the wives of black soldiers were forced to accompany their husbands out of financial necessity, due in large part to the US government's decision not to pay its black regiments. ${ }^{18}$ Another group of black women, slaves, were often contraband of Union armies. After the emancipation proclamation, and as part of the "total warfare" policy on Southern civilians, slaves were confiscated by Union troops traveling through the South. Other slaves became contraband as they voluntarily joined the troops in a bid

\footnotetext{
${ }^{15}$ Catherine Clinton, Public Women and the Confederacy (Milwaukie: Marquette University Press, 1995), $25-28$.

${ }^{16}$ See Thomas Lowry, The Story the Soldiers Wouldn't Tell: Sex in the Civil War (Mechanicsburg: Stackpole Books, 1994), for thoroughly documented work on prostitution.

${ }^{17}$ Schultz, Women at the Front, 16-17.

${ }^{18}$ Susie King Taylor, Reminiscences of My Life in Camp: An African American Woman's Civil War Memoir (Athens: University of Georgia Press, 2006) and Ella Forbes, African American Women during the Civil War (New York, Garland Publishing, 1998), 51-62.
} 
to escape their masters. ${ }^{19}$

Prostitutes and black women were not labeled 'respectable' under the Cult of True Womanhood, which meant that their presence was rarely questioned, but more frequently tolerated as a consequence of male needs. For respectable women though, the confluence of working class women and the corrupted male sphere combined to create a societal perception that the camp was not an acceptable place for them. Despite the opposition, respectable women sought them out. They did not simply abandon social codes, but instead creatively expanded on the idea of proper spheres and women's natural roles to justify their decisions. In this paper I will analyze respectable Southern women, including single women, female soldiers, bereaved women, and nurses to demonstrate how they created separate spheres within the Confederate camps, battlefields and hospitals to allow their presence to conform to nineteenth century gender constructs, despite the outward appearance to the contrary. While the inroads that women were making on the women's rights movement are important to understanding how the definition of the Cult of True Womanhood was being expanded, it is important to note that this survey does not focus on their effect on the movement, or infer that they were blazing new ground by abandoning social and gender codes altogether. Instead, I argue that they actively sought to conform to nineteenth century ideas of women's proper spheres.

In Chapter one I discuss unmarried women who were particularly sensitive to accusations of impropriety. These women wanted to utilize the nearby soldier populations for courting, socialization and visiting relatives, but were limited by acceptable places for women to go. They responded to the challenge by creating distinct, separate spheres in the camps that conformed to nineteenth century modes of propriety, and were helped by

\footnotetext{
${ }^{19}$ Forbes, African American Women, 12-16.
} 
the soldiers in their endeavor. Socializing also took on a different connotation for many Confederate women when they were forced to socialize with and entertain Union soldiers while their towns were under enemy occupation.

Chapter Two looks at the most acute reason women went to camp, as female soldiers. Women soldiers broke numerous gender constructs by cross dressing, fighting, living amongst unfamiliar men, and so on, but once they were exposed as women, they creatively utilized gender stereotypes to justify their actions. These women played on the idea that all women were nurturing protectors and created a response for the press that painted them as such. They also counted on changing attitudes towards women's public involvement to claim a deep seeded sense of patriotism that compelled their decision.

In the third Chapter I look at how death acted as a draw into the camps, analyzing the women who went to camp and battlefield to retrieve the bodies of their husbands, sons and brothers. These women were typically married because single women rarely traveled alone, and as the country waged war, it was incredibly hard to travel so only select family would go. Many women also went to the battlefield as sightseers, in viewing parties, to watch the men fight as a form of morbid entertainment. Many of the viewing parties also acted as relic gatherers, retrieving curiosity pieces and necessities from the battlefield. Many were souvenir hunters, but others took advantage of the high death tolls to obtain items that were hard earned in the Confederacy such as guns, socks, shoes, valuables, money and so on.

The fourth chapter looks at nurses and expands the purview of camp to the hospital. Field hospitals and established hospitals were an extension of the camps because they only housed soldiers and were under the authority of the military. Many were large 
enough to act as a base or camp and created self-supporting communities of soldiers. Few respectable women went to work as nurses because it was work, but those that did created hierarchies, demanded autonomy, refused pay and stipulated the labor that they would do. Nurses received the most initial backlash, but necessity from the mounting casualties quickly changed the Confederacy's policies towards female nurses, leading thousands of women to respond to the call of duty.

In order to argue that these women actively created a separate sphere within the camps, it is imperative to rely on their own 'voices' whenever possible. This meant that my methodology and primary sources centered on female writers chronicling their wartime experiences through letters, journals and memoirs. In the case of female soldiers, who rarely left behind records, I utilized newspaper interviews of ousted soldiers. When a soldier was not directly interviewed I looked at how reporters uniformly interpreted the broader issue of female soldiering and how that mirrored the women's own responses. Because the crux of my argument hinges on how women themselves fashioned a response to the public, or utilized gender stereotypes, it was vital to use their own writings. As much as is possible, I wanted the women to be seen in the ways they saw themselves. Focusing on male journals and letters would have imparted a second-hand, biased perception of these women that imposed more than it revealed. However, at times it was important to show the male perception because they were active participants in creating a separate sphere, and their biases reinforced my argument. Additionally, my methodology largely focuses on Southern women because the war was fought on their land. Southern women were also more exposed to troop movements and encampments, both friendly and hostile. When Southern sources were absent, and I felt that Northern 
women's words could appropriately fill the gap without compromising my argument, I utilized them.

A book that follows a similar methodology is Thomas Lowry's Sex in the Civil War. It is one of the few monographs to deal exclusively with sexuality during the war, and presents it as masculine and one sided. The book is well written and extensively researched, but there is no sense for how women engaged in, elicited, or were affected by sex with soldiers. However, Lowry's purpose is not to discuss women's history, but to expose the gritty underside of war and displace romanticized notions of an unsexed army, essentially revealing the realities of the male soldering experience. Lowry reinforces his argument by utilizing a male-centric primary source base that is solely comprised of male diaries, letters and pornography. I utilize a similar methodology, focusing on an almost fully female source base in order to demonstrate how women created separate, socially sanctioned spheres in camp.

The majority of Civil War primary source records were written by men, but the female population was increasingly literate on the eve of the war, leaving behind unprecedented insight into the female wartime experience. Michael Nelson discusses women's literacy during the war in his article, "Writing during Wartime: Gender and Literacy in the American Civil War," noting that women wrote in personal and public capacities, including as nurses for their patients, as documenters of enemy occupation for their husbands and as private journalists chronicling their own experiences. ${ }^{20}$ The South as a whole was becoming increasingly literate, with only 16 percent illiteracy for men over 20; compared to England which stood at 34 percent in the same time, the South was

\footnotetext{
${ }^{20}$ Michael Nelson, "Writing During Wartime: Gender and Literacy in the American Civil War," Journal of American Studies 29 (2001): 45,48-51.
} 
advancing. ${ }^{21}$ Literate women were typically white, middle and upper class, but records of their literacy rates were not compiled. Many left behind the wartime journals and letters that provide historians with an expansive view of the home front, and in many cases throughout the South, a glimpse of military campaigns. Prostitutes, slaves, laborers and free black women left behind few records, forcing historians to analyze them in different ways, such as through archeology, male sources, and governmental records.

There are no comprehensive monographs on Civil War female camp followers as there are for the women of the Revolution, but historians have compiled works on a few of the subgroups who entered the camps, namely female soldiers and spies. These women were atypical in their time because they broke through gender barriers, a distinction that has elicited extensive research and produced monographs. Female soldiers and spies fall under the purview of "women on the front" and are generally analyzed for motivational factors, the extent of their contribution to the war effort, and their place on the women's rights spectrum. Two of the premier works on female soldiers and spies are DeAnne Blanton and Lauren Cook's They Fought like Demons: Women Soldiers in the American Civil War which takes a biographical approach to the women who broke gender barriers, and Elizabeth Leonard's All the Daring of the Soldier: Women of the Civil War Armies, which assumes a more nuanced look at these exceptional women, analyzing their motivations as well as the mythology that society placed on them.

Other women, such as prostitutes and laborers are largely ignored, or forgotten as integral features of camp life. As mentioned earlier, the topic of prostitution has received

\footnotetext{
${ }^{21}$ Stanley L. Engerman, “A Reconsideration of Southern Economic Growth, 1770-1860,” Agricultural History 49 (1975): 353.
} 
some research by Thomas Lowry, but there is no serious work that looks exclusively at the female prostitute, her motivations or experience. Respectable women such as single white females and wives of officers have earned no published work by historians for their forays into camp, but are typically folded into research on the home front experience. Despite the staggering loss of life, which produced new canons of grieving and gave birth to the embalming industry, research on bereaved women is inadequate as well. Drew Gilpin Faust has written the premier work on death and dying in the Civil War, titled This Republic of Suffering, but little is focused on the women who went to camp to retrieve the bodies of their husbands, brothers and sons. Nurses have received significant work because Clara Barton was the founder of the American Red Cross, and her efforts were begun in the Civil War, plus, the Civil War is regarded as the birthplace of the nursing profession in America. ${ }^{22}$ Camp followers as a whole are likely ignored because of their limited numbers, perceived inconsequence or unsavory reminders of the sexual needs of a romanticized army. During the Revolution, women were camp followers for a simple reason, necessity. Many of the colonists were too poor to support their wives and families while they fought long campaigns, so women followed. During the Civil War, the categories of women and their motivations lay all across the spectrum, producing a field that is unbalanced and tends towards sensationalism, resulting in a cache of monographs on spies, female soldiers and nurses.

The broader subject, 'Women of the Civil War' breaks down into home front versus battle front, and generally analyzes women's contributions to the war effort or the implications of women's mobilization on the suffrage movement. The vast majority of

\footnotetext{
${ }^{22}$ See Stephen Mercedes Graf, On the Field of Mercy: Women Medical Volunteers from the Civil War to the First World War (Amherst: Humanity Books, 2010). Many of the works on Clara Barton are juvenile literature, but many Civil War nurses diaries have been published.
} 
women existed on the home front and supported the troops in socially acceptable ways, such as through canning, knitting blankets and providing other necessities. Particularly in the South, where resources were strapped, women were even more integral to the potential success of the Confederacy. This departure from traditional spheres has led many historians to debate the impact of women's mobilization, despite enfranchisement coming nearly a century later.

Elizabeth Cady Stanton and Susan B. Anthony struggled to accept their own capitulation during the war, particularly as black men were enfranchised but women were excluded, sparking the debate on whether the Civil War positively or negatively affected the movement. Stanton, Anthony and Matilda Joslyn Gage wrote a three volume work just ten years after the war titled History of Woman Suffrage in an effort to show how the Civil War invigorated the movement but had little policy impact. The second volume described the war's effect on the movement, noting, "The social and political condition of women was largely changed by our civil war. Through the withdrawal of so many men ...new channels of industry were opened to them.... and a desire for their own personal liberty intensified. It created a revolution in woman herself." ${ }^{, 3}$ The authors clearly believed that the Civil War was a springboard, forcing a newfound independence and resourcefulness upon women, but ultimately a failure. ${ }^{24}$

Contemporaries of Stanton, Anthony and Gage agreed with their conclusion, but were uncomfortable with women's expanded autonomy. Frank Moore, author of Women of the Civil War: Their Heroism and Self-Sacrifice and L. P. Brockett and Mrs. Mary C. Vaughan's Woman's Work in the Civil War: A Record of Heroism, Patriotism and

\footnotetext{
${ }^{23}$ Elizabeth Cady Stanton, Susan B. Anthony, and Matilda Joslyn Gage, ed., History of Woman Suffrage Vol. 2 (Rochester: Charles Mann, 1887), 23.

${ }^{24}$ Stanton, History of Woman Suffrage, 88-89.
} 
Patience appear to be celebrations of women's contributions to the war effort, but actually reflected popular uneasiness with women's new public personas. Elizabeth Leonard, author of Yankee Women argues that these post-war books were an effort to applaud women while gently nudging them back into their prescribed gender roles, allowing men to resume their rightful place as head of household. ${ }^{25}$ For example, Moore celebrates Kady Brownell, a famous female soldier who followed her husband into battle. On the surface this appears to applaud women's equality, but her story is framed with the condition that she only went to battle to protect her husband, an action that would have been perceived by society as a natural extension of women's nurturing roles. There is no alternative explanation provided for her motivation, such as monetary gain, glory, or reprieve from restrictive gender roles, which were more likely explanations. In many of the Reconstruction and post-Civil War monographs women were applauded so long as their actions could be construed to conform to traditional womanly modes of behavior.

Catherine Clinton supports Leonard's claims in her work The Other Civil War, arguing that the women's rights movement was born during Reconstruction and continued into the mid nineteenth century. At the outbreak of the war women were able to enter the public arena, creating new opportunities outside the domestic sphere, but once the war ended, they were expected to return to pre-war conditions. This situation was essentially like opening Pandora's Box, and left women wanting more. ${ }^{26}$ Nina Silber further engages the discussion in Daughters of the Union, arguing that women had to fill

\footnotetext{
${ }^{25}$ Elizabeth Leonard, Yankee Women: Gender Battles in the Civil War (New York: W.W. Norton \& Company, 1994), 160.

${ }^{26}$ Catherine Clinton, The Other Civil War: American Women in the Nineteenth Century (New York: Hill and Wang, 1999), 80-82, 95-96.
} 
the roles of men, often grappling with responsibilities they knew little about, while still adhering to traditional standards of feminine propriety. ${ }^{27}$

While I am not engaging in the debate over the Civil Wars impact on the women's rights movement, their expanded autonomy does come into play for many camp followers and acted as an additional catalyst and justification. Silber's earlier argument parallels the situation Southern women faced when entering camp. On the surface, women were expected to stay in their appropriate domestic sphere, but the realities of protracted warfare forced them to enter the public eye, and for a portion of these women that meant the camps. However, women did not simply reject their respectability, but instead fashioned an image that conformed to nineteenth century gender constructs, or, the Cult of True Womanhood.

\footnotetext{
${ }^{27}$ Nina Silber, Daughters of the Union: Northern Women Fight the Civil War (Cambridge: Harvard University Press, 2005), 3-10.
} 


\section{CHAPTER 1 \\ UNMARRIED WOMEN IN CAMP}

"The war seems rather incentive to love than a check."

-Emma Holmes, 1862

Septima Maria was a young Southern woman from Charleston who married Union officer Charles Collis on December 8, 1861, just eight months after the war commenced. ${ }^{28}$ Her husband, was an Irish immigrant who mustered the independent 114 th “Zouaves d' Afrique” regiment of Pennsylvania, a unit initially intended as a bodyguard force for Major General Banks. The 114th Zouaves d' Afrique, and other Union and Confederate Zouaves, were modeled after historic French and Algerian troops, a style of regiment known for their Turkish uniforms and European fighting background. ${ }^{29}$ While the Collis' marriage was atypical during the Civil War, since Southern women were renowned for their fierce patriotism and loyalty to the Confederate cause, their meeting was made possible by the mobilization of men and armies at the outbreak of the war.

Collis's status as an officer's wife afforded her many wartime luxuries and provided an excellent opportunity to witness camp life, about which she later wrote. In $A$ Woman's War Record 1861-1865 Collis states that she felt uniquely able to provide a firsthand account of life on the front, writing, "I have no hesitation in calling what I am about to write a 'war record,' ... I served faithfully as a volunteer, though without compensation, during the entire war of the Rebellion. It is true I was not in the ranks, but

${ }^{28}$ Septima Maria Levy Collis, A Woman's War Record, 1861-1865 (Chapel Hill, University of North Carolina at Chapel Hill, 1997), 17.

${ }^{29}$ Collis, A Woman's War Record, 2. Also see http://www.pa-roots.com/pacw/infantry/114th/114thorg.html for more information on the $114^{\text {th }}$ Pennsylvania Zouaves d' Afrique regiment 
I was at the front..." Collis reveals that camp life was not an entirely masculine sphere, but a fluid space where women moved about. The presence of women was largely described as social in nature, their entertainment providing a "very merry, dancing, drinking... and unthinking time. ${ }^{130}$ The sense of normalcy that dances provided was a necessary source of escapism while the troops fluctuated between monotony and fear of impending battles.

However, not all women who entered camp were sex workers, so how did respectable women, such as the ones Collis mentions justify their presence in a space that had many attributes of a brothel? Collis herself provides an answer, recalling an evening of entertainment that demonstrated how young women utilized the camps to socialize without exposure to accusations of impropriety:

It was during this winter that the Fifth Corps, commanded by Major General Warren, gave a magnificent ball, quite unique as to decorations, etc. The ballroom consisted of several hospital tents, and the banquet hall of another. These were all smoothly floored; there were several bands, so that the music was continuous; highly polished rifles in ornamental groups; bright brass cannon, lots of drums, and a sea of bunting; the whole illuminated with clusters of wax candles and Chinese lanterns...

The very superb supper and the waiters, I remember, came from Washington, and an express-train brought an immense number of fashionable people from the North. The costumes of the women were superb, quite as elegant and elaborate as displayed at any similar entertainment in city life. The beautiful Miss Kate Chase was the acknowledged belle of the occasion. The ball did not break up until near morning, and then we poor, tired women, in all our finery, were distributed to our respective tented homes in ambulances and army wagons... ${ }^{31}$

Collis' story revealed that women were accepted in camp so long as they adhered to defined parameters of space. The soldiers created a designated space for the women that was separated from the camp, while still being a part of it, and behaved in a manner

\footnotetext{
${ }^{30}$ Collis, A Woman's War Record, 35.

${ }^{31}$ Ibid., 35-37.
} 
that reflected societal norms during courtship and public activities. The memory demonstrates that both the soldiers and young women were complicit in the "gendered geography of war, ${ }^{32}$ meaning they both actively created a socially sanctioned space within the confines of the camp that was above censure.

$$
* * *
$$

In the spring of 1861 most combatants and civilians believed that the unfolding war would only last six months, but as the death toll escalated and the initial battles yielded into a war of attrition the intensified violence led to an explosion in the marriage rate. "Marriage fever" swept through the country, spurred on by a fear of loss, a sense of social patriotism, romanticism, but most importantly, by the availability of young men. The Civil War mobilized the male population on an unprecedented scale, creating a situation where young women that would have ordinarily been exposed to only a limited number of suitable partners in their rural communities, were now encountering men from all over the country. As many young, white, middle and upper class women entered the camps to socialize with family and potential suitors, another contingent of women was coerced into contact with the enemy. Women came unwillingly to camp because they lived in occupied areas where the situation was exacerbated by officers who demanded that Southern women act as their hostesses and entertain them. Because the war was largely fought on Confederate soil, the majority of Southern women viewed Union

\footnotetext{
${ }^{32}$ Judith Ann Giesberg, Army at Home: Women and the Civil War on the Northern Home Front (Chapel Hill: University of North Carolina Press, 2009), 148.
} 
soldiers as an unsolicited source of oppression, and when they were occupied, not as potential marriage partners. $^{33}$

Many of the privileged young women that came of age during the Civil War, women who would have ordinarily perpetuated the ideals of the antebellum period through marriage and family connections, faced unprecedented circumstances as the war dramatically changed their social landscape. ${ }^{34}$ Antebellum society had produced standards for courting procedures and marriage that young women were unwilling to abandon, even as wartime conditions undermined such prefixes. In addition, the enlistment of women's male relatives positively and negatively altered social customs by providing a link to camps while also creating the loss of chaperones. In considering antebellum traditions and the effect of male enlistment, I will demonstrate why respectable, unmarried Southern women actively sought camps and how the Cult of True Womanhood defined their social interaction with soldiers despite the outward appearance of unrespectability, then delve into the reasons why another segment of the same demographic were coerced into Union camps.

Expectations of marriage are described by Nancy Theriot in Mothers and Daughters in Nineteenth-Century America, as being disseminated by maternal figures and popular literature. Women were essentially raised from childhood to emulate their mother's prescribed role of domestic partner, and assailed by outside sources that further articulated this ideal. The mother-daughter relationship was often complex and intimate;

\footnotetext{
${ }^{33}$ See the Alice Williamson diary for an example of a Southern girl living under Union occupation. Allison Williamson, “Allison Williamson Diary," Special Collections Library, Duke University, http://scriptorium.lib.duke.edu/williamson/

${ }^{34}$ Antebellum. (n.d.). Online Etymology Dictionary. Retrieved November 16, 2010, from Dictionary.com website: http://dictionary.reference.com/browse/antebellum. The word "antebellum" is Latin for "before the war" and was first recorded in Mary Chestnut's diary on June 14, 1862.
} 
young women were typically receptive to the advice and implied expectations of their mothers, which perpetuated the societal view of women's domestic sphere. "I5 "Imperial Motherhood" came to describe the self-imposed idea that women expected to find significance in their roles as wife and mother through an emphasis on suffering and endurance, as well as adherence to societal codes of appropriate behavior and domesticity. As a result, mothers, if financially able, allowed their daughters to enjoy an unburdened childhood, free from housework and domestic training, but ultimately expected them to assume the expectations that accompanied marriage and motherhood. ${ }^{36}$

Eliza Francis Andrews further elaborated on the societal conditions of elite women during the antebellum period in her war-time journal from 1864-1865. In 1908 the journal was published and Andrews was given the opportunity to edit the diary and provide an introduction, in which she identifies the "privileged 4,000," or members of the Southern elite who owned over 100 slaves in 1850 and enjoyed a class consciousness that stemmed from a shared culture and mutual sympathies. ${ }^{37}$ Andrews notes that these great planters, and a few businessmen, dominated the political climate of the South leading to secession. There existed an "ex-officio title of membership" for the elite, which created fluidity amongst the highest social circles throughout the South. Andrews recalled that even their refined language was set apart, another characteristic that set the elite apart. Andrews spoke from personal experience, lamenting the loss of a lifestyle that was “thoroughly wholesome, happy and joyous.",38

\footnotetext{
${ }^{35}$ Nancy Theriot, Mothers and Daughters in Nineteenth-Century America: The Biosocial Construction of Femininity (Lexington: University of Kentucky Press, 1996), 19, 63-64.

${ }^{36}$ Theriot, Mothers and Daughters, 77.

${ }^{37}$ Eliza Francis Andrews, The War-Time Journal of a Georgia Girl 1864-1865, ed. Spencer Bidwell King Jr. (Atlanta: Cherokee Publishing Company, 1976), 1-2.

${ }^{38}$ Ibid., 2-3.
} 
The ability to maintain the lifestyle that Andrews discussed began to break down as the Civil War devastated southern resources. The fledgling Confederate government struggled with the economic consequences created by a protracted war, as well as an economy based largely on agricultural trade, not manufacturing or industry. Wartime conditions became more strained as manpower declined from the mobilization of Southern men, the currency steadily devalued, taxes were raised, food was absorbed by troops, and so on. Economic historians debate the importance of these numerous causal factors, placing the argument within the debate on why the South lost the war. For example, Emory Thomas discusses the juxtaposition between the harsh wartime conditions for Southern civilians and the socialist style expansion of the Confederate government that resulted in urbanization, modernization and the decline of agricultural practices. ${ }^{39}$ Paul Gates and James Huston on the other hand contest aspects of this theory, seeing the war years as a complete collapse of previous prosperity. ${ }^{40}$ Despite the nuanced debate, there is consensus that the war wreaked havoc on the economy, largely shutting down access to goods and services.

The consequences of an overextended economy equally affected the domestic front of the South, leaving women to manage household responsibilities despite diminishing resources. For single women, inflation and trade restrictions limited access to high quality fabrics and decorative accoutrements such as lace and ribbons. ${ }^{41}$ Merchants spiked the price of cloth 100 percent or more, forcing women to make their dresses out of

\footnotetext{
${ }^{39}$ Emory M. Thomas, The Confederacy as a Revolutionary Experience (Englewood: Prentice-Hall, 1971), 83-99.

${ }^{40}$ Paul W. Gates, Agriculture and the Civil War, ed. Allan Nevins (New York: Alfered A. Knoph, 1965), James L Roark, "Behind the Lines: Confederate Economy and Society," in Writing the Civil War, ed. James McPherson and William Cooper Jr. (Columbia: University of South Carolina Press, 1998), 204-206. ${ }^{41}$ Jill Condra and Anita Stampler, Clothing through American History: The Civil War through the Gilded Age, 1861-1899 (Santa Barbara: Greenwood Press, 2011), 145-46.
} 
cotton or calico. Emma LeConte remarked on the poor conditions in her diary on January

23, 1865, noting:

It may be of interest some day to recall the poor style in which we lived during the war, so I shall make a few notes. My underclothing is of coarse unbleached homespun, such as we gave the negroes formerly only much coarser. My stockings I knit myself, and my shoes are of heavy calfskin. My dresses are two calicoes, (the last one bought cost sixteen dollars a yard) ... The homespun cost about eight or ten dollars a yard, - calico is 20 to 30 dollars a yard now, and going higher from week to week. My shoes are 150 dollars a pair. ${ }^{42}$

By the end of the war calico was considered a luxury and soldiers regularly profited by purchasing cotton in the North and selling it back home. John Casler was one such profiteer, noting in his memoirs, "I wanted to take the calico South, as it was a great object at that time. A young lady who could sport a calico dress those times felt rich, as all the wear was homespun.. ${ }^{43}$ Emma Holmes noted in her diary on July 29, 1863 that her household had discovered that their neighbors were selling a significant quantity of cloth at prewar prices, "which they let the girls have at $\$ 2$, a remarkable cheap for these days, when $\$ 4$ or $\$ 5$ is the common price. ${ }^{44}$ The Northern blockade and rising inflation made it difficult for even the wealthiest families to obtain luxuries, but women responded to the challenge by purchasing blockaded items, sewing their own wardrobes, and refashioning old garments. ${ }^{45}$ Eliza Andrews mentioned the difficulty of obtaining luxury garments in a

\footnotetext{
${ }^{42}$ Emma LeConte, Emma LeConte Diary, 1864-1865 (Chapel Hill: University of North Carolina at Chapel Hill, 1998), 10-11.

${ }^{43}$ John O. Casler, Four Years in the Stonewall Brigade (Dayton: Morningside Bookshop, 1971), 259.

${ }^{44}$ Emma Holmes, The Diary of Miss Emma Holmes 1861-1866, ed. John F. Marszalek (Baton Rouge: Louisiana State University Press, 1979), 287.

${ }^{45}$ Condra and Stampler, Clothing through American History, 142.
} 
January 1865 entry, noting, "I expected to wear that beautiful new dress that ran the blockade and I have had so few opportunities of showing it." ${ }^{46}$

Andrews' disappointment reveals that fashion and social engagements were intricately linked, primarily due to fashion's role as a status indicator and defining tenant of femininity, which helped women secure a respectable husband. A reporter for the Richmond Daily Dispatch recognized that fashion and social engagements were on the forefront of women's minds as the war created a "husband catching" frenzy. On July $18^{\text {th }}$, 1861 the Richmond Daily Dispatch printed an article reminding women that traditional modes of womanly behavior were just as important, writing:

"Where do men usually discover the women who afterwards become their wives, is a question we have occasionally heard discussed, and the result invariably come to is worth mentioning to our young lady readers. Chance has much to do in the affair, and then there are important governing circumstances. It is certain that few men make a selection from ball rooms, or any other place of public gaiety, and nearly as few are influenced by what may be called showing off in the streets, or by any allurements of dress. Our conviction is, that ninety-hundredths of all the finery which decorate or load their persons go for nothing, as far as husband catching is concerned. When, and how, then, do men find their wives? In the quiet homes of their parents - at the fireside, where the domestic feeling and graces are alone demonstrated. These are the charms which most surely attract the high as well as humble. Against these all the finery and airs in the world sink into insignificance."

Despite such admonishments, clothing remained a rigid concept that continued to define class and femininity. Dress, as a marker of status, became an integral component to women's acceptance within camps because it separated them from laborers and prostitutes and enabled men to become active players in creating separate spheres. Additionally, this article demonstrates popular consciousness of appropriate spheres for

\footnotetext{
${ }^{46}$ Andrews, Georgia Girl, 71.
} 
courting and how those places reinforced women's ultimate identity, that of wife and mother.

Just as Andrews admitted, many other young women were concerned about the decreasing opportunities for entertainment because societal expectations of matrimony were still strongly reinforced. Unfortunately for the majority of women throughout the South, accessibility to young men necessary for such engagements oscillated. Women typically lost their male relatives to enlistment, the draft or death, a loss experienced on many levels, including a link to non-familial male populations. In addition, approximately 258,000 Confederate soldiers died in battle and from disease, a death rate within the army of 24 percent, which reduced the general availability of men of marriageable age. ${ }^{47}$ Even though local male populations often declined, the war was primarily fought throughout the South, producing transitory populations of young men as the troops camped or fought amidst communities. Therefore, as the home front became increasingly feminine in landscape, women who lived near an encampment experienced temporary surges in their male population, a fact they capitalized on.

The rapidity of the population fluctuation had two consequences, it made many women quick to marry and it made many women widows. Emma Holmes frequently commented on the marriages of relatives and acquaintances around her, noting in her diary on March 16, 1861, "The prospect of war certainly does not tend to depress love affairs, for during the last three or four days I've heard of numerous engagements." ${ }^{, 4}$ Once these women married, the likelihood of their becoming young widows rose steeply. Harriet Perry wrote to her sister Mary Person on October 22, 1862 to explain why she

\footnotetext{
${ }^{47}$ S. Mintz, "Casualties and Costs of the Civil War" in Digital History, http://www.digitalhistory.uh.edu

${ }^{48}$ Holmes, Diary of Miss Emma Holmes, 16.
} 
was not staying with family, writing "I want to stay as near him [Theophilus] as I can while he lives-for I have no idea he will ever return to stay-war makes its widows by the thousand." ${ }^{49}$ The fear of loss was as equal a propellant into marriage as love.

Despite the sense of urgency that precipitated most marriages, young women still expected a specific process of courtship, or appointed 'rules of engagement.' Marriage was viewed as the primary function of women in society, with the ultimate goal being motherhood, and this model became more urgent as the Civil War began to deplete male populations. Women were warned to watch for men of loose character, those that gambled and drank heavily, because their personal habits often left women destitute or physically abused. Frances Cogan points out in All American Girl: the Ideal of Real Womanhood in Mid-Nineteenth-Century America that "sensitivity and tact as well as 'gentle' personal habits are almost as important as education in determining whether a young man is appropriate." ${ }^{, 50}$ Women were not enfranchised and still largely regarded as the property of their husbands which meant that they depended heavily on their male relatives for political, economic and social representation. Therefore, it was of vital importance that women chose a man who was temperate and willing to allow his wife a degree of autonomy, authority and equality. For the women of the middle and upper class, it was important that they married a man of equal social standing. This requirement became even more important as women encountered men from every socioeconomic bracket in the camps, and in their homes. Women were warned that if they could not find

\footnotetext{
${ }^{49}$ M. Jane Johansson, ed., Widows by the Thousand: the Civil War Letters of Theophilus and Harriet Perry 1862-1864 (Fayetteville: University of Arkansas Press, 2000)

${ }^{50}$ Frances B. Cogan, All American Girl: The Ideal of Real Womanhood in Mid-Nineteenth-Century America (Athens: The University of Georgia Press, 1989), 137-143.
} 
a potential suitor that matched her criteria, it was better to not marry. ${ }^{51}$ Emma Holmes frequently noted throughout the war years that she was wary of men due to a fear that they would not live up to her expectations, and despite a fear of becoming an "old maid," Holmes never married. ${ }^{52}$

The 'rules of engagement' varied as women acquired advice from mothers, friends, advice columns and books, but women expected courtship to proceed as it had before the war. For example, it was improper for a young woman to spend time alone in an isolated place with a potential suitor so chaperones were utilized to ensure propriety. Chaperones were not necessarily matronly figures, but often constituted male relatives or large groups of young people that acted in a self-policing manner. In order to become engaged, it was necessary to have the social opportunities that placed men and women together, making entertainment one of the most fundamental aspects of courting. In the exploratory phase, women were encouraged to express their true opinions in face to face conversations to ascertain the man's reaction, which could indicate compatibility. If the couple were forced to correspond through letters they were instructed to gather as much knowledge about the other's views on important matters. These discussions were perceived as critical because they determined power dynamics and whether the husband would encourage the intellectual development of his wife and permit equal say in financial matters. ${ }^{53}$

Historians have debated whether Victorian sexuality indeed reflected the "prim and proper' title assigned to it. Patricia J. Anderson and Michael Mason have written monographs that dispel the idea that Victorian women were prudish or did not engage in

${ }^{51}$ Cogan, All American Girl, 169-70.

${ }^{52}$ Holmes, Diary of Emma Holmes, xxiii.

${ }^{53}$ Cogan, All American Girl, 185. 
premarital sexual relations. They expand upon the topic, tackling many misconceptions including non-existent homosexuality, restrictive gender roles, secretive masturbation, etc, that modern society projects onto the Victorian Era. ${ }^{54}$ Jeffery Turner on the other hand, argues in Dating and Sexuality in America, that the Victorian Era was a transitional period, where sexual repression was no longer widely accepted, but dating and gender roles remained largely traditional. ${ }^{55}$ The evidence is clear that nineteenth-century American sexuality did not parallel social rhetoric, but the young women who entered the camps and their male hosts actively aligned their behavior to reflect social mores. In their formative years young women were inundated with literature and parental advice that conveyed societal expectations of female decorum, so when the war created new opportunities for courtship women transferred their parlor charms to mess halls.

The high marriage rate was indicative of the women's response to their circumstances, marrying local men before they enlisted or utilizing the nearby male populations in camp to socialize. The white, upper class women who socialized in camp were aware of the 'sordid nature' that an all male population, away from their families and exposed to prostitution, could produce. ${ }^{56}$ Despite this, there existed in camp a hierarchy of wealthy and middle class women who engaged in activities that would have been a part of their customary social calendar, including dances, dinners, card games, and so on. The women also required a pretext for visiting the camps, often visiting male relatives or officers who were acquainted with their families.

\footnotetext{
${ }^{54}$ Patricia J Anderson, When Passion Reigned: Sex and the Victorians (New York: Basic Books, 1995), and Michael Mason, The Making of Victorian Sexual Attitudes (New York: Oxford University Press, 1994).

${ }^{55}$ Jeffery S. Turner, Dating and Sexuality in America, a Reference Handbook (Santa Barbara: ABC-Clio, 2003), 6 .

${ }^{56}$ Nettie Fondren asks her fiancée, Robert Mitchell, to refrain from sleeping with prostitutes in a letter to his camp on April 2 and May 18, 1862, Drew Faust, Mothers of Invention: Women of the Slaveholding South in the American Civil War (Chapel Hill: University of North Carolina Press, 1996), 291. MitchellFondren Family Civil War Letters.
} 
Emma Holmes' diary provides an example of young women who sought out entertainment from nearby camps. Holmes was the daughter of a wealthy plantation owner, a proud Confederate and Charlestonian, and often noted her desire to marry, if only to avoid becoming an "old maid," a status most women abhorred because it meant social and financial dependency on their parents. The Civil War proved to be both a hindrance and catalyst to her marriage prospects, as it was for many women. On one hand she came into contact with more men than was likely to have happened before the war, but she also met numerous 'rough' figures that did not suit her standards of gentlemanly behavior. Those she did admire never returned her affections, so Holmes remained an unmarried schoolteacher for the rest of her life. Holmes was emblematic of the women in her class; she was an ardent secessionist, frequently recording her hatred of the Union cause, well educated, and a proud Southerner convinced that "right" would prevail. She took a paternalistic view of slavery, praising the loyal slaves who protected their masters and possessions against Union soldiers, but reproached those who fled or rebelled. Her contempt and fear of the black Union soldiers she encountered was palpable, and she often noted the "irresponsibility" of black units that had few or no white officers. ${ }^{57}$

For the first few years of the war, Holmes' wealth allowed her to spend the majority of her day in pursuit of entertainment, often to the extent that the war seemed to become a distant backdrop in her daily life. The majority of entries are filled with notations on the many activities of the day, people who visited, and her social calls. A frequent part of her social calendar included visiting her brothers Edward and Willie at their camps outside Charleston. On November $16^{\text {th }}, 1861$ Emma noted her first visit to a camp while visiting her brother Willie,

\footnotetext{
${ }^{57}$ Holmes, Diary of Emma Holmes, Introduction.
} 
It was my first view of an encampment, and camp life \& everything was interesting to me. During the parade Walter C \& Sam R joined us, \& we all returned to the tent where we sat till long after the moon had risen $\&$, as we passed through the long crowded rows of tents, we caught many a glimpse of the scenes within; while without, groups stood around camp fires where we saw a number of servants $\&$ coffee pots...

The two key elements in this entry are time and space. The group, which contained five women, was willing to stay in camp until "long after the moon had risen" without concern for their reputations, and felt comfortable entering the men's sleeping quarters. These two aspects seemed to contradict standard courtship and entertainment practices, but was not noted by Holmes to be unusual or prohibited by her family.

All camps were intensely male dominated spheres, and the men who resided in them encompassed every socioeconomic status. As a result, the few women who dotted the landscape were subjected to naked and wounded flesh, prostitution, drunkenness, foul language and innumerable other 'social evils'. John Casler, a soldier in Stonewall Jackson's brigade, provides an unapologetic glimpse into camp life, conveying numerous instances of lewd behavior, theft and public drunkenness as standard behavior in camp, once noting "I told my Captian how I had run the blockade for a canteen of whisky on his responsibility, but he just laughed at the trick." ${ }^{, 59}$ Holmes' party avoided these obstacles because they were visiting a male relative of Emma's and under chaperone. The party also utilized a new sense of autonomy that existed for young women who were living at home without their fathers and brothers to provide guidance. ${ }^{60}$ Holmes' father had died before the war and her brothers enlisted, leaving her mother as the sole parental figure. Expanded autonomy did not mean that young women abandoned social mores and

\footnotetext{
${ }^{58}$ Ibid., 77.

${ }^{59}$ Casler, Four Years, 55-56, 99.

${ }^{60}$ Victoria E. Ott, "The Self-Sufficient Daughter," Confederate Daughters: Coming of Age during the Civil War (Carbondale: Southern Illinois University Press, 2008), 73-99.
} 
entered the camps alone; they simply became their own moral compass, often reinforcing the etiquette and respectability they had learned.

Their adherence to tradition created the sphere in camp that stridently conformed to acceptable social behavior for women of their class, while providing the opportunity to meet societal expectations of marriage. When socializing in camp, they limited their encounters to men of equal status, including relatives, long standing family friends, acquaintances of their relatives, and officers. ${ }^{61}$ As Eliza Andrews recorded in her memoirs, there was a collective sense of community and shared culture amongst the Southern elite, which allowed the women to socialize with men they may not have necessarily known, but were accepted based on class status. These men were familiar with traditional social customs and actively participated in the creation of a separate, and sanctioned women's sphere in the camp.

Holmes articulated the way that soldiers created a feminine sphere in an April 1862 entry. Her brother and a few officers invited the group of women to their tent and recreated a social scene that would have been common in any parlor. The soldiers provided the women with champagne and fruit cake, but were unable to acquire china, so the women made do with tin plates. Holmes noted that the lack of appropriate dinnerware revealed the "rigors of camp life." What is striking about many of these parties was the lack of departure from social etiquette despite the war's strain on resources. For example, the party returned to camp the following day and was provided an extravagant meal of lobster, turkey and ham, in regular "city style." The officers and men flirted with the women and Holmes noted that Lieutenant O'Brien had captured her interest as a potential

\footnotetext{
${ }^{61}$ Ott, Confederate Daughters, 103.
} 
suitor. ${ }^{62}$ Septima Collis had also noted the separation of camp for women when the troops physically set up the dance hall for the elite women of Washington. The men were complicit, engaging the women with the shared expectation of meeting potential partners, or simply seeking a break from the monotony of camp life.

Holmes also offered an example of the potential dangers that women could face in camps. She told a story about a family that went to find the remains of Dr. E. L. Buist under "the flag of truce," and after locating the body which had been honorably buried, the family went back to camp and found that, “when our gentleman passed the men's quarters, the scene of debauch there with the Negro women was so dreadful and so revolting that the officers were actually ashamed $\&$ had to apologize $\&$ said that after victory they were quite unable to control their men."63 Holmes likely recorded this story in her journal as a justification of the moral superiority of the Confederate cause, but it highlights the threat to respectability that women in camp faced. Other women were more frank in their assessment of Confederate camp life. Nettie Fondren asked her fiancée Richard Mitchell to refrain from the amours of prostitutes while he resided in camp and away from her affections. ${ }^{64}$

The women who did enter the camps mitigated their exposure by visiting relatives and soldiers of equal social status, and in return, the men created a space that differed drastically from the harsh conditions in camp. Even when women seemed to be walking the line by engaging with the larger male population they were accompanied by their male relatives or family friends and treated with greater respect than the female laborers

\footnotetext{
${ }^{62}$ Holmes, Diary of Emma Holmes, 141.

${ }^{63}$ Holmes, Diary of Emma Holmes, 102.

${ }^{64}$ Nettie Fondren asks her fiancée, Robert Mitchell, to refrain from sleeping with prostitutes in a letter to his camp on April 2 and May 18, 1862. Mitchell-Fondren Family Civil War Letters.
} 
and prostitutes in camp. John Casler recalled a visit from his sister Sallie, who came into camp accompanied by their cousin Smith Casler. Her visit was a very important reminder of home and prompted Casler to forge furlough paperwork so that he could visit her, fifteen miles away from Camp Winchester after her departure. ${ }^{65}$ Holmes herself toed the line between mixing with the larger camp population and propriety when she visited Edwin to try "the famous camp pudding, of bread soaked in molasses \& fried in bacon" on March 12,1862. "When it was ready, we went to the mess tent a few steps off, \& I took lunch in true soldier style." It was Edwin's presence that validated Holmes' interaction with the soldier population.

Belle Boyd, famed Confederate spy, also recorded the necessity of family to camp life. In the opening of her memoir, Boyd recalled her first memory of camp at Harper's Ferry, which she had decided to visit with a few friends because, "like myself, they had friends and relations to whom they felt their occasional presence would be a source of encouragement and solace..." ${ }^{, 66}$ Boyd and Septima Collis both reiterated in their post war memoirs that the presence of women in camp provided a respite from the monotony and fear, and fostered a sense of normalcy. Boyd elaborated, writing that at Harpers Ferry,

[t]he ladies, married and single, in the society of husbands, brothers, sons, and lovers, cast their cares to the winds, ... [and] resolved that whatever calamity the future might have in store for them, it should not mar the transient pleasures of the hour... I fear that at this time many fond vows were exchanged and many true hearts pledged between the girls of the neighborhood and the occupants of the camp... ${ }^{67}$

The majority of young women who were willing entrants into camp were drawn by family and romance, two factors that maintained a reciprocal relationship. It was

\footnotetext{
${ }^{65}$ Casler, Four Years, 60.

${ }^{66}$ Belle Boyd, Belle Boyd in Camp and Prison (Baton Rouge: Louisiana University Press, 1998), 76.

${ }^{67} \mathrm{Ibid}$.
} 
through their male relatives and family friends that women had access to potential suitors, and they utilized this resource widely. The men in camp made space for the women because they provided comfort and entertainment during a punishing experience, particularly in the South where conditions in camp were exceedingly poor.

Not all single women entered camps to visit relatives or meet eligible men, some became unwilling 'women in camp' as their homes were engulfed by occupying forces. Camps and nearby towns were linked to one another as troops acted as occupying forces, provided protection, used resources or waged war. Front Royal, Virginia for example, experienced an ever-changing shift in Union and Confederate occupation due to its strategic importance to “Stonewall” Jackson's Shenandoah campaign. In early 1861 approximately one hundred Union troops set up tents on the courthouse lawn and imposed martial law. These circumstances forcibly imposed camp conditions upon nearby populations; women and children primarily suffered as soldiers foraged for food and valuables, often leaving families destitute. Lucy Rebecca Buck recorded the occupation of Front Royal in her diary entry of May 3, 1862, noting:

It was a lovely day and we spent the greater portion of it upstairs at the windows from which with the aid of our spy glass we could witness a great deal of what transpired on town during the day. Could see citizens as they were every now and then arrested by the patrol and marched off to "headquarters." Could see the tents pitched in the courthouse yard and all the bustle and confusion consequent upon the first forming of an encampment. $^{68}$

The Buck family estate, named Bel Air, became a central location during Union occupation because of its proximity to the courthouse. Buck recorded that "uncouth Yankees" frequently demanded meals from their dwindling supplies, which were already

\footnotetext{
${ }^{68}$ Lucy Rebecca Buck, Sad Earth, Sweet Heaven: The Diary of Lucy Rebecca Buck, ed. Dr. William P Buck (Birmingham: The Cornerstone Publisher, 1973), 59.
} 
depleted due to the repeated search and seizure of their food lockers. ${ }^{69}$ The situation was exacerbated two weeks after the May 1862 occupation when an additional two thousand soldiers arrived under General Kimball and set up in the Bel Air fields. The scene of destruction traumatized Lucy, who watched their fences be dismantled, well used up, livestock stolen and fields trampled. But more upsetting to her, was her father's despair as he watched his life's work be destroyed in a single afternoon. ${ }^{70}$ General Kimball pitched his tent directly next the Buck house, stating that he did so to prevent troops from molesting the family, but William Buck was so concerned about the number of male soldiers residing near his daughters that he invited the General to live in the upstairs wing of their house. The camps were not a safe place for young women, without the presence of family, or in this case, an officer. Lucy was resentful that their family was dependent on the soldiers to protect them, bitterly recording "what would Alvin and Irving think could they know that their mother and sisters and little brothers were in the centre of a hostile camp dependent upon their oppressors for protection from insult and injury."71

To add insult to injury, Buck and her mother were forced to socialize with the officers, pastors and soldiers who entered the home. The rank and file soldiers frequently demanded meals, which the family could not refuse, and the officers were regularly provided breakfast which taxed the estate's already reduced circumstances. Buck noted a range of emotion towards the men, sometimes appreciating their gentle, polite manners and other times despising their sense of entitlement and superiority, in one entry noting

\footnotetext{
${ }^{69}$ Ibid., 58.

${ }^{70}$ Buck, Sad Earth Sweet Heaven, 65-66, 122.

${ }^{71}$ Lucy Rebecca Buck, Shadows on my Heart: the Civil War Diary of Lucy Rebecca Buck of Virginia, ed. Elizabeth R. Bauer (Athens: University of Georgia Press, 1997), 76.
} 
"Twas a very warm day and we spent it mostly upstairs growling at the hard Yankees.",72 However, just a few nights later Buck recorded that she had entertained Union Col. Van Buren and listened to his stories about his travels across Europe, stating "Twas entertaining to listen to his accounts and we were thus engaged until bed time."73 The troops made some attempt to reciprocate hospitality, by gathering the army band to "play for the ladies." 74 More frequently though, they used their music to annoy Buck by playing Confederate songs or patriotic Yankee tunes, prompting Buck to angrily write, "Thieves! They come to steal our liberty, steal our property, our slaves, and, not satisfied with this robbery, actually steal our National Music..."75 Entertainment and socialization took on new connotations for the young women under occupation, or residing near enemy camps, for they were often forced to be hospitable out of fear or by intimidation.

Many of the previously mentioned threats posed by camps, including food appropriation, forced entertainment of officers and destruction of property, paled in comparison to the experiences of some Southern women whose lives were threatened by occupying forces. Allison Williamson was a young girl of sixteen who briefly recorded her wartime experiences so that she might discuss life on the home front once her brothers returned from war. Unlike many of the other surviving women's wartime journals that discuss shortages, social engagements and daily life, Williamson began documenting the war crimes of General Eleazer E. Paine, who Williamson referred to as Our king, Tempest, old hurricane, Thunder Storm, and Old Marster. Paine was an unusually cruel General that was eventually relieved of his duties, but inflicted ruthless

\footnotetext{
${ }^{72}$ Buck, Shadows on my Heart, 123.

${ }^{73}$ Ibid., 124.

${ }^{74}$ Buck, Shadows on my Heart, 69.

75 Buck, Shadows on my Heart, 77.
} 
marshal law on Gallatin, Tennessee. Paine frequently had Southern men executed in horrific ways without trial for alleged spying or Confederate allegiance. He also routinely terrorized citizens and arbitrarily placed the town under laws, that if broken, often meant the death penalty. After Confederate forces massacred black Federal soldiers at Fort Pillow, Williamson predicted in her journal, "Old Payne and all the rest are mad about the Fort Pillow affair. This vengeance will be taken out on the citizens of G. in a few days." ${ }^{, 76}$ Williamson was particularly resentful that the Union soldiers were using her school and other large buildings to build a "Freedmans" school, sarcastically remarking that her job prospects included working as an assistant in their university. ${ }^{77}$ For the women such as Williamson and Buck who resented the presence of the camps, the way they approached the men was geared towards survival, and not romance or family connections.

The women who came of age during the Civil War were forced to contend with abnormal circumstances. They were raised by women who embodied the standards of the antebellum era, which dictated that women would get married and have children, an expectation they passed onto their daughters. Further, there was a process that young men were expected to follow when courting, but the mobilization of men and the high death rate made these expectations more challenging to fulfill. The transitory nature of troops meant that women encountered more potential partners from across the South, but they were also denied access to these men unless they had a relative or friend that could provide the opportunity of a visit.

\footnotetext{
${ }^{76}$ Allison Williamson, “Allison Williamson Diary,” Special Collections Library, Duke University, http://scriptorium.lib.duke.edu/williamson/, 15.

${ }^{77}$ Williamson, Alice Williamson Diary, 18-19.
} 
Women used their relatives and family friends as access points to the camps, often forming groups to visit. Visiting relatives and friends was a traditional pastime that naturally extended into camp. Even if the women stayed until late at night, they did not cross any social barriers because they were accompanied by family. Elite women were careful to distance themselves from the multitudes in camp by exclusively socializing with men of the same class, whether that was family or officers. Part of this was to assert their place on the social hierarchy, but it also served a necessary function; if women only socialized with men of the same class they were free to become romantically involved. Women could reasonably expect that officers were gentlemen who would abide by traditional courting procedures, so they accepted offers to attend dances, as Collis noted about the refined women of Washington.

The men that accepted women in camp were careful to create the sphere that adhered to appropriate social codes. They produced dances, held dinners and played games that mimicked traditional courting procedures. The men were cognizant of the realities of camp life, and attuned to the risk women took when entering, so they shielded them from it. Men became central players because the women provided the comforts and familiarity of home. Camp life was hard, dirty and monotonous which made men want to enjoy the entertainment that women provided. For most soldiers, who were unfortunately camped far from home, the furlough was a desired commodity that provided a crucial link with reality and loved ones. For the men that were stationed near relatives, women acted as their relief.

Emma Holmes witnessed countless engagements and marriages during the war years, wryly noting, "The war seems rather incentive to love than a check." She knew 
that many women were becoming widows almost as fast as they were married, and that women in the South feared this fate. But instead of checking impulsive marriages, women were more eager than ever to marry in case their lover died before they had the chance. Men and women were both willing participants, which opened up the door for young, unmarried women to use the camps as an opportunity to meet suitable men, and for men to create a separate sphere for the women that conformed to nineteenth century ideas of propriety. 


\section{CHAPTER 2 \\ FEMALE SOLDIERS IN CAMP}

Sarah Rosetta Wakeman began her life like many young women, as a member of a poor agrarian family in central New York. She was the primary source of manual labor and advice for her father, a man who ran up debts with little hope of repaying them. At the outbreak of the war, Sarah made an unusual decision; she decided to dress as a man and head to New York City in hope of finding employment. She was confident she could make significantly more money as a man than a woman because women's job prospects were typically limited to teaching or domestic labor. Her decision to leave home to create a better life for herself, as well as provide financial support to her family, produced mixed emotions; she had never been particularly comfortable at home, but was unwilling to sever ties. Wakeman worried about the family's struggles and disputes, but firmly stated that she would never return home to live permanently. She initially took an unspecified job for $\$ 4$ for half a month of manual labor, but later joined a coal barge to make $\$ 25$ a month. These earnings were a significant leap from what domestic occupational labor paid. On her barge, Wakeman encountered Union recruiters who offered $\$ 152$ to enlist, a sum equal to one year's pay. Wakeman seized the opportunity and began making enough money to send home significant sums. ${ }^{78}$

\footnotetext{
${ }^{78}$ Lauren Cook Burgess, ed. An Uncommon Soldier: The Civil War Letters of Sarah Rosetta Wakeman, alias Private Lyons Wakeman 153 ${ }^{\text {rd }}$, New York State Volunteers (Pasadena: The Minerva Center, 1994), 175.
} 
Unfortunately, throughout her three year enlistment Wakeman was more concerned with the financial and social affairs at home to provide more than a glimpse of camp life. This is a deep disappointment for historians because her letters are the only direct, candid words we have on the subject by a female soldier. In this sense though, Wakeman was no different than the millions of other male soldiers who desperately sought information on the welfare of their loved ones back home. However, one gets a sense that army life was no different for a woman soldier than a man; they both experienced the drudgery of picket and guard duty, provided arduous manual labor, feared the public outbreaks of disease that riddled the camps, hated the long marches and Southern heat that brought unaccustomed discomfort, and finally, trepidation at impending battles. The ordinariness of their experiences is extraordinary, and if Wakeman is an example, the women were fully prepared to perform any duty a man did without seeking relief based on their typically smaller stature and strength.

I suspect that part of Wakeman's disdain for returning home was due in part to the questions she would have had to answer about her behavior. She notes in a letter addressed to her parents on December 28, 1863 that "I Don't care anything about Coming home for I [am] aShamed to Come...I have enjoyed myself best since I have been gone away from home than I ever did before in my life." ${ }^{, 79}$ Wakeman's new identity allowed her a degree of freedom that she had never before experienced. Despite the fact that women of the laboring classes were much more equipped for army life than their middle class counterparts, it was still highly unusual for women to assume a male identity. There was a nuanced difference between manly behaviors that allowed a woman to help her family subsist on a farm, and assuming all the attributes of masculinity in order to live

\footnotetext{
${ }^{79}$ Burgess, An Uncommon Soldier, 58.
} 
away from home as a man. Poverty did not mean that women were freed from gendered social restraints; they just approached such limitations with more practicality. Wakeman stated, "I knew I could help you more to leave home than to stay there with you." 80 Wakeman was public about her decision, her family and friends were fully informed, but certain actions and statements indicate that the situation was not entirely accepted. Wakeman's siblings even referred to her as their brother to avoid awkward conversations with acquaintances and town citizens. Private Lyons Wakeman was never discovered to be woman, even when she lay dying of chronic diarrhea in her camp hospital. We will never know how she would have responded to queries about her decision, but this chapter will demonstrate that women from all classes, once discovered, responded in specific and calculated ways that made their decision appear socially acceptable.

The Civil War brought many changes to traditional gender stereotypes, particularly blurring the line between public and private spheres for women. With the great mobilization of troops, many women responded by forming organizations such as the Sanitary Commission that provided basic necessities to the troops. This activism, coupled with the bourgeoning women's rights movement on the eve of war, left many women with the hope that their new found forays into the public sphere would expand their rights. Despite the fact that the suffrage movement was largely halted during the war years, the mobilization of women acted as preparation for the years ahead. The Civil War can ultimately be viewed as a transitional period where women made headway in loosening perceptions of women's competence, capabilities, and place in the public arena. However, the progress that was made along the continuum of the women's rights movement did not stray far from the boundaries of social acceptability, and those

\footnotetext{
${ }^{80}$ Burgess, An Uncommon Soldier, 9.
} 
regulations were never far from the minds of women who came into contact with the camps. $^{81}$

During this transitional time, a subaltern group of women on both the Confederate and Union sides crossed the gender barrier to act as male soldiers, cross-dressing females, and spies. Whether these women were motivated by a social collective that was redefining what it meant to be a woman, patriotism, or had a natural propensity for adventure is difficult to determine. Some sources indicate multiplicity; an innate tendency to break with traditional feminine roles but also self-assurance that their actions would be forgiven by a cautionary, yet intrigued, society. A few notable women such as Belle Boyd and Loretta Velazquez determined to profit from their adventures, putting forth sensational memoirs that were aimed to garner fame and fortune. DeAnne Blanton and Laura Cook, authors of They Fought like Demons: Women Soldiers in the American Civil War, note that female soldiers likely grasped at the opportunity to step outside the confines of their gender to seize power, opportunity and independence. ${ }^{82}$ Elizabeth D. Leonard puts forth the straightforward motivation of patriotism, in All the Daring of the Soldier but further expands on the lure of monetary gain, rebellion against gender expectations and love for brothers and husbands. ${ }^{83}$

There are fundamental obstructions to the study of women soldiers according to Blanton and Cook; they simply did not leave behind diaries, only three letters home have survived, and only two memoirs were published. Blanton and Cook point out that many

\footnotetext{
${ }^{81}$ Mary P. Ryan, "Gender and Public Access," in Habermas and the Public Sphere, ed. Craig Calhoun (Cambridge: The MIT Press, 1992), 279.

${ }^{82}$ DeAnne Blanton and Laura Cook, They Fought like Demons (Baton Rouge: Louisiana State University Press, 2002), 4-5.

${ }^{83}$ Elizabeth D. Leonard, All the Daring of the Soldier (New York: W. W. Norton and Company, 1999) 22740.
} 
of the women who did fight in the war were from rural, immigrant families that placed little emphasis on female education. Hence, in a largely literate male soldiering population that sent home millions of letters and recorded events in diaries, hardly a trace remains of women soldiers. As a result, their stories and experiences are largely lost to history, and historians are limited to the few published works, newspaper accounts and male soldier's journals in order to obtain a sketch of their lives and motivations.

While the focus of They Fought like Demons is not to place the female response to exposure within a framework of the Cult of True Womanhood, Blanton and Cook briefly explain the societal expectations that these women defied. Women were expected to always appear "demure, submissive, pious and concerned only with home and family. Women who gave any appearance of stepping outside of highly restrictive female roles risked being labeled 'not respectable." The authors do note that these gendered standards did not permeate the working and lower class to the extent that it did the elite, but that all women were still aware of the consequences their actions could have on their reputations and the alienation they faced if discovered, as Sarah Wakeman encountered. ${ }^{84}$

As with many gender studies it is difficult to conduct a bottom-up approach since women on the fringes of society rarely leave behind writings. Due to the nature of female cross-dressing and insertion into the male dominated war sphere, few of these women as previously noted, left records. Accordingly, my methodology is based from the few published and recovered diaries and memoirs, male journals, US records and newspaper accounts. Mary Livermore of the US Sanitary Committee, writing her memoir in 1889 recalled, "Someone has stated the number of women soldiers known to the service as little less than four hundred. I cannot vouch for the correctness of this estimate, but I am

\footnotetext{
${ }^{84}$ Blanton and Cook, They Fought like Demons, 2-4.
} 
convinced that a large number of women disguised themselves and enlisted in the service, for one cause or another, than was dreamed of." ${ }^{85}$ In response to the uncertainty of accurate figures and limited resources, I have expanded this chapter to include Northern female soldiers. I will rely upon Union women sparingly but they fit into this chapter because the Victorian-era rejection of female cross-dressing and exhibiting male characteristics applied universally to Northern and Southern women, regardless of socioeconomic status or their motivation.

Most authors on the subject of women spies and soldiers such as DeAnn Blanton, Lauren Cook, and Elizabeth Leonard focus primarily upon motivation and causation, placing women's departure from conventional gender constraints on the continuum of the women's rights movement or comparing their experiences and abilities with male soldiers. These women lived in Victorian America, creating certain gendered pressures they normally adhered to, but their motivations, be it money, fame, or patriotism, will never be fully understood. The truth for these women is irrelevant, but the myth that they created in response to the revelation of their gender is what is critical.

Society had a hand in female soldiers public response, producing the mold and criteria that these women were expected to conform to. Many of these women found themselves in the paradoxical situation of being ousted as cross-dressers, while providing an explanation to the public for their behavior that allowed them to retain their conventional womanly attributes. This goes back to the masculine sphere of the camp, where women found an excuse to coexist in a space that respectable women, in theory, were not permitted. Similarly, reputable women used the camps to socialize and court men, creating a protected space for themselves within the camp. I will demonstrate that

\footnotetext{
${ }^{85}$ Mary A Livermore, My Story of the War (New York: Arno Press, 1972), 119-120.
} 
female spies and soldiers were cognizant of the barriers they were breaking, and in response wielded public sentiment in on itself to craft a response to their subversive activities that allowed them to remain within the cult of domesticity, virtuous womanhood and social acceptability.

The decision to depart from traditional modes of womanhood began with looking the part. In order to successfully act as a spy or soldier, many of these women donned male attire and emulated the behavioral traits of men. Loretta Velazquez recalled her transformation into male attire in her memoir The Woman in Battle by noting, "[b]raiding my hair very close, I put on a man's wig, and a false moustache, and by tucking my pantaloons in my boots, as I had seen men do frequently...I managed to transform myself into a very presentable man." ${ }^{86}$ Later, Velazquez was dressed as a man to prove to her husband William, who was trying to dissuade her from entering the army, that she was capable of passing herself off as a man in both manners and form. Despite his tactics to expose her to lewd male behavior in taverns, which he assured her would be replicated in camp, Velazquez refused to be daunted. Velazquez understood that to remain concealed over a significant amount of time, she would need more permanent accoutrements. She eventually commissioned special body suits made with wire framing and padding that went under a uniform to conceal her gender and create more bulk. ${ }^{87}$

Many women who acted as male soldiers had to take similar measures, such as binding breasts and cropping hair. The transformative nature between male and female clothing in the nineteenth century was significant, and likely acted as a symbolic and physical barrier being crossed. Drew Faust argues in Mother of Invention: Women of the

\footnotetext{
${ }^{86}$ Loretta Velazquez, The Woman in Battle: A Narrative of the Exploits, Adventures and Travels of Madame Loreta Janeta Velazquez, ed. C.J Worthington (New York: Arno Press, 1972), 53.

${ }^{87}$ Ibid., 57-59.
} 
Slaveholding South in the American Civil War that women connected the physical manifestation of their clothing to their self-perception as women and society's resulting limits on women. Just as layers of petticoats and hoops were physically oppressive, so to was society's opinion on how women were to behave. This feeling led many women to lament their sex, seeing male attire as a means to break free from their physical and social constraints. ${ }^{88}$

Faust notes Sarah Morgan, who was so afraid to cross the cross-dressing barrier that she removed her pet canary from her bedroom when trying on her brothers' suit. ${ }^{89}$ While humorous, this demonstrates the seriousness with which society viewed transvestitism. Female soldiers were making a definitive and rebellious decision when they chose to don male attire. A good example of social rhetoric can be found in 1851 when the Bloomer Costume was introduced to American women as a safe and healthy alternative to their long confining dress layers. The Bloomer Costume was comprised of a dress that went mid-calf and a pair of trousers that were worn under the dress and covered the remainder of her legs. Those who advocated against it singled out the trousers as a masculine rejection of femininity. They associated the trousers with politics, the link being that only men wore trousers and only they were enfranchised. If women wanted to wear trousers it implied that they were rejecting their feminine, domestic sphere to enter the public arena with men. ${ }^{90}$ The outfit was also criticized under sexual and religious terms, being noted for its immodesty and impiousness. When viewed in this light, the

\footnotetext{
${ }^{88}$ Drew Gilpin Faust, Mother of Invention: Women of the Slaveholding South in the American Civil War (Chapel Hill: University of North Carolina Press, 1996), 220-221.

${ }^{89}$ Ibid., 220.

${ }^{90}$ Jill Fields, "Erotic Modesty: (Ad)dressing Female Sexuality and Propriety in Open and Closed Drawers, USA, 1800-1930," in Gender and Sexuality 3 (2002), 497.
} 
decision of women to dress as men demonstrated a greater departure from social norms because it was a direct assault on the political and gender hierarchy.

Since Victorian women are generally perceived as overtly feminized, in large part due to their dress and domestic capacities, a doubt arises on their ability to pass as men. However, a few factors worked in their favor. First, boys as young as fifteen (and some younger) joined regiments to act as bugles, drummers, assistants and so on, so it was common for camps to have young, feminized looking males in their midst. The comparison allowed women to pass as youthful males, unable to grow beards and having a clear complexion. It is simply incorrect that all women who acted as female soldiers must have been androgynous or unattractive, a perception that probably reflects the social stigma of their actions more than their actual appearance. Newspaper articles routinely reflected on the women's looks, often remarking on their comely appearance. The second favorable factor was traditional Victorian modesty. Both men and women were not accustomed to public exposure of their bodies and many soldiers remarked in their diaries or letters about various attempts to gain privacy in the crowded camps. Women could utilize this, as Velasquez did, to bathe and go to the restroom in the safety of the nearby woods. Many of the women who have been lost to history were likely more successful at concealing their gender because they moved fluidly between male and female spheres, and had the additional fortune to not be caught by doctors tending to wounds.

Not only did women have to appear to be men through their clothing, they also had to convince their fellow soldiers and officers through their behavioral traits. Aside from physical attributes, such as a defeminized walk or explaining away a high voice through age, some women struggled with mimicking the mental perspective of men 
because it differed so greatly from their insular world view. Velasquez wrote about her first shocking experiences in camp and being exposed to the lewd conversations of her fellow soldiers, stating, "the manner in which too many men are in the habit of referring to the opposite sex in conversation among themselves is, in my opinion, thoroughly despicable." ${ }^{, 91}$ Velazquez attempted to avoid such conversations and actively sought out soldiers who wanted to discuss more academic subjects. She also noted that she avoided strong drink, only taking hard cider or sarsaparilla, and spent much of her free time playing cards. However, other women dove more fully into traditional male behavior, getting arrested for drunkenness, fighting and causing public disturbances.

Public fascination with the daily life and experiences of these soldier women led to polarized opinions on female soldiering. Richard Hall, author of Women on the Civil War Battlefront argues that mid-nineteenth century gender conventions assumed that these "bold and cheeky" women must be socially deficient in some way. ${ }^{92}$ Velazquez noted that many men in camp discussed whether women should be allowed to fight, with mixed reactions. She recalled in her memoirs, "Some of the men with whom I have been associated have spoken in respectful...terms concerning women serving as soldiers; but too many have had nothing but vileness to utter on the subject." ${ }^{93}$ The subject had apologists on every side, fueling a political debate that centered on the themes of the women's rights movement. As in the bloomers debate, women soldiering was an affront to masculinity and challenged the popular opinion of separate spheres. For many men, conceptualizing that women were physically and mentally capable of performing the arduous tasks required in camp and on the field challenged their notions of masculinity.

\footnotetext{
${ }^{91}$ Loretta Velazquez, Woman in Battle, 59.

${ }^{92}$ Richard C. Hall, Women on the Civil War Battlefront (Lawrence: University Press Kansas, 2006), 121.

${ }^{93}$ Loretta Velazquez, Woman in Battle, 60.
} 
The war produced a dilemma for society of where to place female patriotism on the spectrum of appropriate behavior. On one hand women were expected to remain in their private spheres, but the war quickly necessitated an output of labor and supplies that the Confederacy could not meet. Women galvanized into action, created commissions and organizations that provided supplies to the troops, a fact that was quickly appreciated and acknowledged. The Louisiana Journal summed up women's role in an article penned at the outset of the war, noting on October 21, 1861, "The citizen soldier shows his devotion to his country by taking up arms for its defense, but the women have a high and noble duty to perform in stimulating us and sanctifying us, as it were, for the performance of that duty." The article goes on to say that women's patriotic duty was to gladly and proudly send their husbands, sons, and brothers to war without a show of emotion that might weaken their resolve. Women walked a fine line working in the public sphere; it was allowable so long as the motives and the ends were for the benefit of their country and loved ones at the front.

Under these limits there was not much room for women who desired to do more than knit socks and send foodstuffs; but many women went to the front regardless. So how did these women view themselves and create an image for the outside world that allowed their actions to be sanctioned? It began with the archetype Joan of Arc, who Robin Blaetz argues "crossed and blurred the boundaries between male and female behavior and thus revealed the artificiality and permeability of the lines delineating sexual difference." ${ }^{94}$ For many Southern women, Joan of Arc was a romantic figure that escaped Renaissance gender constraints to dress as a soldier and lead a holy crusade in

\footnotetext{
${ }^{94}$ Robin Blaetz, Visions of the Maid: Joan of Arc in American Film and Culture (Charlottesville: University Press of Virginia, 2001), 8-9.
} 
the Hundred Years War. Their own desires to give more directly to the secession cause, coupled with frustrations over their own Victorian constraints, led many to use Joan of Arc as a model. ${ }^{95}$ Blanton and Cook discuss the role of female soldiers in nineteenthcentury America, utilizing the descriptive phrase "Female Warrior Motif" to describe the romanticized vision of women becoming soldiers for love of a man or country. ${ }^{96}$

A popular literary genre sprung up that idealized fictional soldier women but the lead characters often drew upon Joan of Arc and Deborah Sampson, a more contemporary example from the Revolutionary War. The novellas followed a pattern; a woman enlisted for the sake of her lover, behaved heroically in battle, saved or nursed her wounded love, and then returned to the contented domesticity she had desired all along. A few titles included Justina the Avenger, The Lady Lieutenant and, Minnie Ball, Vivandiere at Bull Run. ${ }^{97}$ These books fit within a Victorian framework so long as the woman went to war in order to protect a loved one and ultimately returned to her proper place. The idea of women acting as natural protectors to their families within the home was encouraged and expected, so it was not surprising for these women to do so in a public arena. Ultimately, the tension between prescriptive patriotism, Victorian gender ideologies and literary tradition influenced how female soldiers' conceived of and justified their actions.

On December 19, 1863 a New York Times article published the exposure of a female soldier, alluding to the novella her story would inevitably inspire:

\footnotetext{
${ }^{95}$ Blaetz, Visions of the Maid, 16.

${ }^{96}$ Blanton and Cook, They Fought Like Demons, 148-61.

97 "Book Review-They Fought Like Demons, Women Soldiers in the Civil War by DeAnne Blanton and Lauren M. Cook" in The Smithsonian Associates Civil War E-Mail Newsletter, Volume 5, Number 6, http://civilwarstudies.org/articles/Vol_5/deamons.shtm
} 
Yesterday, a rather prepossessing looking lass was discovered on Belle Isle, distinguished among the prisoners of war held there. She gave her real name as Mary Jane Johnson, belonged to the Sixteenth Maine Regiment, and had been a prisoner for some time. She gave as an excuse for adopting her soldier toggery, that she was following her lover, to shield and protect him when in danger. He had been killed in battle and now she would have no objection to return to the more peaceful sphere for which nature, by her sex, had better befitted her"

The heroine of a novel yet to be written in Yankeedom was considerably sunburned and roughened by the hardships she had encountered, but still retained the marks of some womanly comeliness, which would be heightened by a calico frock and crinoline.

This account can be examined under two different, but overlapping themes. First was the aforementioned literary tradition based off the romanticized female warrior motif and the second is nineteenth century gender ideology that explains how the two can coexist. In the groundbreaking article that defined and articulated the Cult of True Womanhood, Barbara Welters identified four categories of behavior that women were required to obey for social acceptance, including piety, purity, submissiveness and domesticity. Welters uses multitudes of women's "self-help" sources such as magazines, newspapers, books, columns, etc., to show a definite collective social ideology that actively attempted to relegate women to their private sphere and defined specific modes of conduct. However, the rules were so rigid that true womanhood created a flux of doubt about women's ability to adhere to them. During the war, where necessity called forth a response that ran contrary to true womanhood, women began to experience doubt and confusion in the face of expanding opportunities. ${ }^{98}$ Other women responded to their changing worlds by trying to expand the definition of true womanhood, creating new womanhood. $^{99}$

\footnotetext{
${ }^{98}$ Barbara Welter, “The Cult of True Womanhood 1820-1860,” American Quarterly 18 (1966): 2, 174.

${ }^{99}$ Ibid., 174. Also see Mary Louise Roberts, "True Womanhood Revisited" which examines the changing meanings of true womanhood into new womanhood. For more current articles that develop the idea of the
} 
An expansion of the definition of true womanhood can be found among the women who took up arms, dressed as male soldiers and went into camp. They did not completely break with the cult, but chose to define their actions in a way that expanded its meaning. Many women, when ousted as soldiers, made up stories such as Johnson's where they stated that they had followed a lover or husband into war with the desire to act as his protector and would now gladly return to their natural state of domesticity since he was dead. Many of these men remained nameless, were proclaimed dead, or the woman had decided not to disclose the fact that she was serving in his regiment. They also often provided vague, unaccountable details that make many of their stories suspect. However, Welters argued that one of the most sacred duties in the Cult of True Womanhood was that of domesticity and under this rule women were to act as their husband's nurses and caregivers. When female soldiers were discovered, they often said they joined to protect a loved one, a strategic answer that would have assured a skeptical public that these women were just acting out, if in extreme, on their natural instincts.

Johnson was not alone, many similar stories appear in newspaper accounts that were circulated throughout the country. For example, the account of Fanny Wilson and her companion Nellie Graves is recorded by the Daily Alta California on October 8, 1864. Their story shadows the 'following a lover into battle genre,' invoking a sense of literary fiction more than real-life narrative. The girls were travelling west to visit family when the war broke out. Upon finding that their lovers had joined the same regiment they devised a scheme to disguise themselves as soldiers and join the regiment themselves, but

cult of true womanhood see also: Diana Di Zerega Wall "Sacred Dinners and Secular Teas: Constructing Domesticity in Mid-19th-Century New York," Historical Anthropology 25 (1991): 69-82 and Deborah L. Rotman, "Separate Spheres? Beyond the Dichotomies of Domesticity," Current Anthropology 47 (2006):666-674 . 
not to reveal their identities to their suitors. They went as soldiers until Fanny's nameless lover was shot at Vicksburg. She sought out his cot and demonstrated her great love through unrelenting care and nursing, but his wounds proved fatal. The two girls themselves fell sick and were discovered by attending nurses. After a full recovery they were dismissed and parted ways, but remained dressed as soldiers fighting in other regiments. $^{100}$

While the article goes on to justify the girls actions with a claim that "every now and then, in spite of all preventatives, something will occur a little out of the nature of things...something a little romantic," the tone of the story acts as the real apologist. The girls story fit into an expanded definition of the Cult of True Womanhood, an expansion that was necessary to accommodate the demands of war. A further example of this genre is recorded by the Daily Alta California on June 28, 1863, when it prints the story of Annie Lillabridge who was deemed so devoted to a lieutenant she met while working in her parents' store, that she donned male attire and followed him to camp. She did not reveal herself to him, even after being shot, but shadowed his every move as a protector. Eventually discharged for being discovered as a woman, she stated that she would attempt to reenlist just to be near him. These women were fully cognizant of society's expectations and whether their stories were true or not, they were aware that they had to frame their responses in a way that didn't overly challenge the social order.

The New York Times records a story that was likely more fiction than fact on October 9, 1861 about Hatty Robinson who was arrested for public drunkenness and wearing "boy's clothes" for seven months. The article notes that she provided testimony that attempted to justify her scandalous behavior, stating, "I was on my way to Harrisburg,

${ }^{100}$ Daily Alta California, “A Romantic Story,” October 8, 1864. 
Penn., where I intended to change my apparel for female attire and return to the regiment, at Washington, as a nurse." Her statement is a two part calculated effort; she notes that she intended to change into women's clothing, demonstrating her preference for female attire, and shares her contingency plan to return to her regiment as a nurse. The nursing aspect is important because nursing was eventually viewed as an appropriate profession for women who were regarded as natural caregivers, plus the fact that the Confederacy desperately needed women to reform their failing hospital system. ${ }^{101}$ Robinson is unique in attempting to justify her behavior through an occupation and not through marriage, an aspect of true womanhood that was itself developing. Robinson does address her marital status, claiming to be married to Lieutenant Fuller of the $46^{\text {th }}$ Pennsylvania, an important factor in the propriety of her staying in the camps, but the mention is brief and vague. Her marital status, whether true or not, would have assured readers that she was not a prostitute because of her claim that her gender was no secret in camp. Robinson explicitly states that the soldiers, camp doctors and officers were fully aware of her sex, and that she enlisted properly, which meant a full physical exam. If she had been a single woman, known by the soldiers to be a woman, Robinson would have likely been regarded as a prostitute by the public and lost her respectability.

The Abingdon Virginian newspaper retold the story of Mrs. Amy Clark on January 30, 1863, highlighting her "self-sacrificing" acts of bravery:

Among the strange, heroic and self-sacrificing acts of a woman in this struggle for independence, we have heard of none which exceeds the bravery displayed and the hardships endured, by the subject of this notice, Mrs. Amy Clark. Mrs. Clark volunteered with her husband as a private, fought through the battles of Shiloh, where Mr. Clark was killed-she

\footnotetext{
${ }^{101}$ Phoebe Yates Pember, A Southern Woman's Story: Life in Confederate Richmond, ed. By Bell I. Wiley (Atlanta: Morningstar Books, 1959), 15-16.
} 
performing the rites of burial with her own hands...Her sex was discovered by the Federals and she was regularly paroled as a prisoner of war, but they did not permit her to return until she had donned female attire. $^{102}$

Since this report is not a direct interview with Amy Clark, it is interesting that the writer chose to place her within a framework of true womanhood without her explicit prompting. This indicates that not only did the women grapple with their place in society, but society responded by imposing its ideological worldview on them. For Clark, true womanhood manifested as perfect devotion, where she went so far as to bury her husband "with her own hands." Patriotism comes into play in this article by showing the tension between true womanhood and its expanding definition. Many women saw their love of country as an extension of their love for their families, and Southern women were particularly noted for their fierce patriotism. Clark's loyalty to the cause is applauded, but it is discussed as an extension of her devotion to her husband, justifying her actions.

There was a dichotomy between expressions of nationalism and gendered expectations for women, and while women were fully cognizant of the events unfolding around them, they hesitated to join in the virulent rhetoric. ${ }^{103}$ Drew Gilpin Faust discusses women's hesitancy to act publicly for a cause they held dear in Mothers of Invention: Women of the Slaveholding South in the American Civil War, stating, "they acted with considerable doubt, with reluctance and apology, longing to behave as ladies but declining to stand aside while history unfolded around them."104 Women were expected to walk the line between patriotism, which was required for the success of the Southern cause, and womanliness, which demanded exclusion from the political arena.

\footnotetext{
102 “A Female Soldier," in The Abingdon Virginian, January 30, 1863.

${ }^{103}$ Drew Gilpin Faust, Mothers of Invention: Women of the Slaveholding South in the American Civil War (Chapel Hill: University of North Carolina Press, 1996), 10-11.

${ }^{104}$ Faust, Mothers of Invention 12.
} 
Patriotism took many forms including aid societies, nursing, hosting soldiers in the home, feeding nearby troops, providing homespun clothing items, and so on; but for other women patriotism manifested as a desire to fight, so the cult of domesticity necessarily expanded to include the nation as the object to be protected. ${ }^{105}$

On March 26, 1864 the Big Blue Union newspaper reprinted a famed article from the Detroit Advertiser about "Emily," a nineteen year old girl who entered the Union army after having visions of becoming a second Joan of Arc. She was considered so delusional that physicians suggested she be sent to Ann Arbor, Michigan for respite, but the fantasies refused to be quelled and Emily eventually escaped from her home to enlist. She survived the Kentucky campaign but was eventually given a mortal blow to her left side by a Minnie ball at the Battle of Lookout Mountain. The doctor, upon discovering her sex, told her to dictate a last note so that her parents might know her fate. She dictated a heart-wrenching note that asked for her father's forgiveness and reiterated her desire to serve her country. ${ }^{106}$ This story played out flawlessly in reader's imaginations because it had all the elements of literary fiction. Whether by design or not, the Joan of Arc theme was intended invoke the romanticism of female warriors. The popularity of the story also demonstrates the expanding and evolving public toleration for female public patriotism.

Female soldiers were often critically reviewed for their background and social standing. Nineteenth-century America, particularly in the South, still lived under a rigid class system and it was easier to place these women within the confines of true womanhood if they merited its distinction. The women that were hailed for their patriotism or love of a man were often noted to be of distinguished, unsoiled reputation.

\footnotetext{
${ }^{105}$ Faust, Mothers of Invention, 16-17.

106 “A Female Soldier-Her Sad History,"Big Blue Union, March 26, 1864.
} 
"Frank Martin" was one such soldier, who served in two regiments and performed her soldier duties exceedingly well. She was discovered by fellow soldiers who knew her and her parents, but incredibly, was allowed to continue serving. A reporter noted that "Her conversation denotes more than ordinary accomplishment, and, what is stranger than all, she appears very refined in her manners, giving no evidence whatever of the rudeness which might naturally be expected from her late associates." ${ }^{107}$ Martin was able to rise above the 'manly' influences of camp life that would have roughened most soldiers, but her background and education saved her from its denigration. Even after discovery, Martin fit within the Cult of True Womanhood because she retained her womanly attributes.

However, as mentioned in the outset of this chapter, with Sarah Wakeman as the archetype, female soldiers were largely from the rural laboring class and most likely joined to receive a steady income, escapism or patriotism. The reality of women's motivations was largely overlooked, so long as they provided a response that fit within the framework of true womanhood and were not discovered while engaged in overtly male activities such as drunkenness, disturbing the peace, theft, prostitution and so on. If they were, newspaper accounts were not so favorable and did not attempt to romanticize their actions, but criticized their behavior based off traditional gender and class constructs. It is ironic that poor women largely gained more equality and autonomy from their subversive behavior than they had as 'traditional women' before the war.

As the war concluded, the literary narrative of women's contributions began to shift. Alice Bahs discusses the change in "The Feminized Civil War: Gender, Northern Popular Literature, and the Memory of the War, 1861-1900," by analyzing popular

107 “A Romantic Story” in The Smoky Hill and Republican Union, June 6, 1863. 
women's magazines, journals and newspapers. Despite a focus on Northern domestic contributions, Bahs points out that during the war literature encouraged all women's participation and patriotism, including amongst Southern women. ${ }^{108}$ This trend continued through the beginning stages of Reconstruction, and in the South it fell into the "Lost Cause" narrative. By the 1880s and 1890s most historians, authors and veterans focused on military exploits, leaving little room for women's contributions. Until recently, women were largely ignored and forgotten as determining factors in the war, particularly women soldiers. ${ }^{109}$

Frank Moore penned one of the most famous post-Civil War collections on women's contributions. The majority of Moore's work is on the home front contributions of respectable, middle class white women; contributions that largely fit within the confines of true womanhood. His focus indicates that Moore was as much trying to celebrate women's wartime efforts as place women back into the margins of their domestic spheres. Moore's inclusion of famed Civil War soldier Kady Brownell appears on surface level to deviate from the mold, but she too adheres to the nineteenth century perceptions of acceptable womanly behavior discussed in this chapter. She is celebrated for following her husband into battle, nurturing and serving both him and her fellow soldiers. Kady is repeatedly praised for her bravery and skill, but Moore is clear that she is more of a caregiver than active soldier. Even her soldierly duty as color bearer is

\footnotetext{
${ }^{108}$ Amy Bahs, "The Feminized Civil War: Gender, Northern Popular Literature, and the Memory of the War, 1861-1900," in The Journal of American History 85 (1999): 1461-1463.

${ }^{109}$ Please see information on Lauren Cook Burgess, author and Civil War Reenactor who sued the National Park Service, and won, in 1989 because fellow reenactor's refused to allow her to engage in reenactment activities at the Battle of Antietam because her peers erroneously believed that women did not fight and were arguing for strict authenticity. She sued for discrimination, but has gone on to prove that hundreds, if not thousands, of women fought for the blue and grey. This is an example of pervasive misunderstandings of women's direct, front-lines contributions to the war.
} 
utilized to stop friendly fire, reiterating woman's familial role as peacemaker. ${ }^{110}$ After her husband Roger was wounded and unable to return to active duty, "Kady had no thought of anything more but the plain duties of the loving wife and the kind friend."111

Writing over thirty years after the war, George Cary Eggleston's 1898 Southern Soldier Stories, demonstrates the extent to which the cult of true womanhood prevailed, even amongst common soldiers. The book is a compilation of his and other's experiences during the war and despite the lack of categorization many of Eggleston's personal narratives are corroborated. However, a few of the stories defy reality because they too closely align with nineteenth century narratives of women's proper sphere in life.

Whether the stories are fact or myth is irrelevant because they tell us more about common societal perceptions of women, which is its own truth. The story titled "Twenty-One" is about beautiful, wealthy and respectable Charlotte Hope who met Eggleston's unit as a local expert on the land around Hope Mansion, near Munson Hill, a region that was divided between loyalist and rebel supporters. Hope promptly fell in love with Lieutenant Wilds and the two became engaged. Wilds was killed in an ambush and Hope decided to avenge him by becoming private Charlie Hopper, joining the regiment in a bid to kill 21 Yankees, the age of her lost lover. She risked her life, eventually killed 21, and immediately died from a gunshot wound after shooting the final Yankee Officer. ${ }^{112}$ This story could have been an interpretation of a newspaper account of a female soldier, or just the product of an active imagination. Either way, it has all the elements of an archetypal

\footnotetext{
${ }^{110}$ Frank Moore, Women of the War: Their Heroism and Self-Sacrifice (Hartford: S.S. Scranton \& Co., 1866), 55-60.

${ }^{111}$ Ibid., 64.

${ }^{112}$ George Cary Eggleston, "Twenty-One" in Southern Soldier Stories (New York: Macmillan Company, 1898), 97-104.
} 
Joan of Arc, but fused with the criteria of the cult of true womanhood. Her status, beauty and devotion to her lover were the image of true womanhood that Eggleston conveyed.

The reason writers such as Eggleston and the reporters who interviewed female soldiers placed these women within the familiar and accepted confines of the Cult of True Womanhood, despite their behavior to the contrary, was because there was not another framework by which to judge them. It was widely accepted that women's sphere was in the home and her primary function was to be a devoted mother and wife. The Cult of True Womanhood, while not being articulated as such during the nineteenth century, was an incredibly entrenched concept that permeated every class of society on some level. However, these constructs were not entirely imposed on female soldiers; the women adopted them and projected that image as well. For many women who were discovered, they probably feared the reaction they would receive once home, and formed a response for the papers that society would understand and accept.

Female soldiers such as Velasquez demonstrated that the male dominated sphere of camp was actually rife with women. This was able to occur because the Civil War opened up new avenues for women to be engaged in the public sphere even while stalling the burgeoning women's rights movement. However, the Cult of True Womanhood continued to be a determining factor, particularly in the South. However, the war also created a new sense of independence and autonomy for women who were left at home to act as heads of household. Mobilization and a need for women's contributions to the burgeoning Confederacy laid the groundwork for expanded assimilation into the public sphere. It was at this juncture that female soldiers were able to utilize loosening restrictions to justify their actions. They stated that their choice was for love of man or 
country, extensions of their rightful sphere as women, but society embraced them as romanticized, independent female warriors. In turn, female soldiers were able to wield this romanticism to craft an image for the public that allowed them to remain within the Cult of True Womanhood. 


\section{CHAPTER 3 \\ DEATH IN CAMP AND ON THE BATTLEFIELD}

The common denominator between the North and the South during the war was their experience with death. After 1862 , the casualty rates rose dramatically, and by the end of the war approximately 600,000 men had lost their lives. Death permeated every facet of life and no one escaped its effects. Death began as a controlled construct, with rules and procedure, but the war eventually made this impossible. Death on such a large scale became a logistical problem, as well as an emotional one, that drove women into the camps. Women went to camp and the battlefield to locate the remains of their relatives, they formed viewing parties that used death as an entertainment form, and became relic-gatherers who looked for objects as mementos or out of necessity. In this chapter the sphere of camp is extended into the battlefield. Just as hospitals were an extension of camp, the battlefield and camp were inextricably linked by the concentration of troops and regulation of the government. It was this combination of temporality, military regulation and the masculine sphere that separated the camp, field and hospital from other civilian areas and defined their distinctiveness.

Logistically, the transition between camp and field was possible because the camps were built to be temporary cities during the fighting season and easily broke down. ${ }^{113}$ The two also merged as battles lasted for days and soldiers had to sleep during

\footnotetext{
${ }^{113}$ See description of soldier's accoutrements and camp life at www.nps.gov/archive/gett/soldierlife/cwarmy.htm
} 
the conflict, creating micro camps out of the field. Frank Aretas Haskell, a Lieutenant in Sixth Wisconsin Voluntary Infantry recorded his sleeping arrangement at Gettysburg, writing to his brother, "Just as the dusk of evening fell, from Gen. Meade, the Second Corps had orders to halt, where the head of the column then was, and to go into position for the night...Arms were stacked, and the men lay down to sleep, alas! many of them their last but the great final sleep upon the earth." ${ }^{.14}$ Out of ten major land battles, nine were multi-day, forcing officers to find strategic places away from shelling for their soldiers to rest, but often times, men were responsible to find their own shelters.

Thomas Almond Ashby was thirteen when the Civil War broke out and offers a unique perspective of death. His home was situated in the Shenandoah Valley, which meant he witnessed numerous battles, including Port Republic, Manassas, Kernstown, and saw the troops pass through on the way to Gettysburg. After the Battle of Manassas, Ashby described the extensive burial process that was necessary to bury the hundreds of men who had died, explaining how governments, troops, and civilians dealt with the rising death toll. Ashby recalled these developments, writing:

I well remember the sorrow at the first death in the hospital... His funeral and burial were marked by the most profound respect. A small military company, on guard duty in the village, turned out to give him a military funeral...Our citizens, - men and women, boys and girls, - turned out to follow the remains of this poor fellow to the cemetery... When the casket was deposited in the grave a squad of soldiers fired a salute over the grave and paid all the military honors possible on such an occasion.

A few days later a second death occurred in the hospital. This poor fellow was escorted to his grave by a few citizens and a squad of soldiers that fired a salute and then retired. Very soon another poor fellow died, and this one was buried in the simplest way. As the days came and went deaths followed so rapidly that the new cemetery grew and grew till it soon became a city of the dead... later many unknown were placed in the ground, - men whom it has never been

\footnotetext{
${ }^{114}$ Frank Aretas Haskell, Battle of Gettysburg (New York: Harvard College Library, 1918), 15.
} 
possible to identify. ${ }^{115}$

Eventually, the burials degraded even further as citizens "hurriedly covered their remains with dirt and stones as best they could." ${ }^{116}$ In just a few days after Manassas, the death toll rose so high that the local citizens were forced to drastically depart from longheld burial practices. Burials became problematic throughout the country as soldiers and families grappled with shifting perceptions on the sanctity of the corpse. Men were eventually buried en masse, no longer separated from the animals and earth by coffins, usually in shallow graves or large multi-use pits, and without proper attire or ceremony.

Women responded in fear to the disintegration of the burial process on the battlefield because it challenged their long held ideas of the "Good Death." This breakdown propelled them into camps, hospitals and battlefields to unearth the remains of their relatives with the hope of completing as much of the burial process as possible. The dying process was standardized in the nineteenth century by procedural expectations that ensured a good death. The good death was ideally comprised of consciousness to the end, acceptance of the condition, a sign of faith in God and a final departing message. ${ }^{117}$ The procedure was not entirely intended to comfort the person dying, but to reassure those left behind. If the person died properly, their relatives could be confident that their loved one was in heaven. When men died in battle, especially if they died instantly, it went against the idea of death being a familial matter, and it worried their relatives that

\footnotetext{
${ }^{115}$ Thomas A. Ashby, The Valley Campaigns Being the Reminiscences of a Non-Combatant While Between the Lines in the Shenandoah Valley During the War of the States (Chapel Hill, University of North Carolina at Chapel Hill, 1998), 57-59.

${ }_{116}$ Ashby, The Valley Campaigns, 60.

${ }^{117}$ Drew Gilpin Faust, This Republic of Suffering: Death and the American Civil War (New York: Alfred A. Knopf, 2008), 6-17, Mary Jeffreys Bethell, Mary Jefferys Bethell Diary: January 1, 1861-December 1865, (Chapel Hill: University of North Carolina, 2000), Nov 20, 1862 and Feb 12, 1863 entries about the deaths of her servant and friend, their preparedness before death and the need for a sign of faith.
} 
they hadn't had time to die properly, assuring their salvation. ${ }^{118}$ Fellow soldiers tried to mitigate this fear by writing soothing letters about the nature of the loved one's death, assuring that they had died well, but thousands of soldiers were simply lost in the confusion of war. ${ }^{119}$

An intrinsic part of the good death was the presence of the body so that it could be prepared for burial in the family plot; but the war made this impossible. Families were denied the assurance of a good death and even worse, denied access to the bodies. Some women simply refused to accept this situation and traveled to battle sites with very little information in a bid to find their loved one's body. The situation was exacerbated by the fact that bodies often remained on the battlefield, in unmarked graves or in mass pits for weeks, producing severe decomposition that made them impossible to identify. At the outset of the war, as Ashby reported, care was taken in each soldier's death, but as more soldiers died, that became increasingly impractical, largely because the bodies posed a serious health risk. Women were presented few options in retrieving remains; they could accept the uncertainty of a battlefield burial, they could pay for the body to be embalmed and shipped home, or they could go to the camp or battlefield to retrieve it and escort it home.

Few women went to the lengths required to obtain bodies because the war made travel virtually impossible. Northern women were often forbidden from crossing the blockade into the South, where the majority of fighting took place, so they had to compel a high ranking officer to issue a pass for travel. Even if the pass was obtained,

\footnotetext{
${ }^{118}$ Faust, Republic of Suffering, 10, 17.

${ }^{119}$ Ibid., 15-17.
} 
transportation was uncertain and could take weeks due to delays. ${ }^{120}$ For Southern women, communication was very poor throughout the South because the new Confederate government was ill-equipped to create a postal system, and as a result women frequently experienced a delay in receiving death notices. By that time, the body had likely decomposed past identification. ${ }^{121}$

One woman in a unique position to overcome these obstacles was Mrs. John F. Phelps. She was a loyal woman living in Confederate sympathizing Missouri, and married to a Colonel in a loyal Missouri regiment. When her husband's commander was killed at the battle of Wilson's Creek, the New York Times reported on the extreme measures she took to retrieve his body, writing the following story on December 4, 1861:

On the afternoon after the battle of Wilson's Creek, it was noticed that the rebels had determined to cut out the heart of Gen. Lyon and preserve it as a trophy over the United States Army. Mrs. Phelps, learning of this outrage on the slain General, armed herself...thus armed, she drove to Mr. Phelps camp by nightfall, and there, all alone, guarded the body of General Lyon. When ordered by the rebels to give up the body, she positively refused, and declared they must cut out her heart before they could get the heart of the General. There, all alone, she stood guard during the whole night...Having thus obtained her cherished object, more dear to her than life, she accompanied it to her residence, and there interred it in the best manner she could. All this was done in the absence of her loyal husband, who, in consequence of his duties as a Colonel, could not be present to accompany his noble wife in performing this work of loyal humanity. ${ }^{122}$

Whether the Confederate soldiers truly intended to cut out the heart of the General remains unknown, but the article does reveal that the perceived threat endangered the possibility of a good death. This current ran so deep in society that Mrs. Phelps, who was

\footnotetext{
${ }^{120}$ For an example of why Northerners were unable to travel South, see, "Rebellion," New York Times, February 4, 1863 which discusses the cessation of issuing civilian passes due to danger of impending battle and the destruction of railroad lines.

${ }^{121}$ See, J. Smile, "Waiting for the Mail," Richmond Daily Dispatch, August 24, 1861 for a poem written about the hardships of delays in the mail when one is waiting for news of a loved one.

122 “A Brave Woman,” New York Times, December 4, 1861.
} 
not a relative of the General's, was willing to go to extreme lengths to assure his burial rite. The article went on to say that Mrs. Phelps intended to bring his remains to her home "in order to inter it in her garden or on the farm, with all the respect in her power toward the commander of the loyal army." If the rebels had taken his body, it would have been impossible to assure a proper burial. There was a profound fear of men simply disappearing into the folds of war, particularly as the war accumulated more casualties and men went missing or died without identification. Women throughout the South were forced to deal with shoddy records, loss of bodies, and mass burial pits that challenged their long-held confidence in a good death which included a home burial for their relatives. In response, women who were willing to traverse the country, or lived near a battlefield that their relative was engaged in, went in search of the remains. For the countless others, innovations in embalming made lengthy train rides a possibility for decomposing corpses. ${ }^{123}$

Another concern raised in the article is about Mrs. Phelps traveling alone. The war granted greater degrees of autonomy to the women left at home, but the majority of women still abided by antebellum notions of women's proper spheres. Upper class and single women did not typically travel alone because they were perceived as unable to traverse the public domain or susceptible to accusations of impropriety. Instead, they travelled with a male relative or a mature female companion. For the women who did go to camp to retrieve the remains of their relatives, the decision was not taken lightly and was often met with skepticism. Even after traveling, the battlefield was not viewed as an appropriate place for women. When locating a body, women rarely had reliable

\footnotetext{
${ }^{123}$ See, Robert G. Mayer, Embalming: History, Theory and Practice (New York: McGraw-Hill Medical Publishing Division, 2006), and Faust, "Burying: "New Lessons Caring for the Dead"” in This Republic of Suffering.
} 
information to go by and had to search through battlefields and camp hospitals. They

were exposed to the mass graves, decomposing bodies and the horrific scenes that Ashby recalled. For these reasons, non-soldiering male relatives or friends were more likely to retrieve the body of a family member, but in limited circumstances, women were the only option available if their family insisted on recovering the remains.

Constance Cary Harrison was one such woman left on the home front in Richmond. When the Battle of Seven Pines took place on the outskirts of Richmond, the women of the town prepared for the eventual casualties. Many of the women had relatives fighting in the battle and intended to provide convalescent care or to retrieve the bodies if possible. Harrison's memoir provides a firsthand look at how Southern women were able to use their proximity with more ease than Northern women to recover bodies:

On the 31st Johnston assaulted the Federals, who had advanced to Seven Pines! It was so near that the first guns sent our hearts into our mouths, like a sudden loud knocking at one's door at night. The women left in Richmond had, with few exceptions, husbands, fathers, sons, and brothers in the fight. All went about their task of preparing for the wounded, making bandages, scraping lint, improvising beds...During the night began the ghastly procession of wounded brought in from the field. Every vehicle the city could produce supplemented the military ambulances. Many slightly wounded men, so black with gunpowder as to be unrecognizable, came limping in on foot. All next day, women with white faces flitted bareheaded through the street and hospitals, looking for their own... Hearing that my cousin, Reginald Hyde, was reported wounded, two of us girls volunteered to help his mother to search for him through the lower hospitals. ${ }^{124}$

Many of the Southern women who entered the camps to recover a body were opportunistic like Harrison and only came when they were able to travel with relative ease. Despite the challenges that Southern women faced in the logistics of traveling,

\footnotetext{
${ }^{124}$ Constance Cary Harrison, Recollections: Grave and Gay (Chapel Hill: University of North Carolina at Chapel Hill, 1998), 82-83, accessed June 30, 2011, http://docsouth.unc.edu/fpn/harrison/harrison.html.
} 
receiving messages about the loss of a loved one, or facing social scrutiny for traveling alone, they were in a better position to reach their relatives in a timelier manner than Northerners. The women of Richmond, like many that had relatives fighting nearby, capitalized on their proximity to provide the best possible care for their relatives, or to assure a good death if that was necessary. Underlying every reason women gave for entering the camps to retrieve bodies was the collective social adherence to the good death. As the Civil War eked away at the sanctity of the corpse and made superfluous the ceremony tied to funerals, society responded by demanding that the good death be upheld whenever possible. It was because of this that women were able to make inroads into the camps, and enter a sphere that was not regarded as an appropriate one for them.

While death was the vehicle that led women to enter the camps in search of their relatives, it also drew out curiosity in others. As troops fortified, groups of viewing parties would pour onto the battlefield to watch the carnage unfold. At the outbreak of the war viewing parties were more commonplace because of the initial fervor and excitement, but the practice never abated, and civilians often ended up in the crossfire. Women were commonly included in these parties as Septima Collis noted after the Battle of Petersburg, writing, “A little party of distinguished sight-seers had just come down from the North... they consisted of "Prince" John Van Buren and his charming daughter, Mrs. Stoughton and General and Colonel Stoughton, Mr. Arthur Leary, Mrs. Paran Stevens, Miss Reed and some others whose names I regret to have forgotten." $" 125$ In the turmoil of the battle the sight-seers had to be escorted to the newly captured Confederate capital at Richmond for their safety. Despite the dangers, viewing parties and women

\footnotetext{
${ }^{125}$ Septima Collis, A Woman's War Record 1861-1865 (Chapel Hill: University of North Carolina at Chapel Hill), 57-58, accessed May 12, 2011 http://docsouth.unc.edu/fpn/collis/collis.html.
} 
used the battlefield as a source of entertainment.

Civilians around the country found out that the scenes on the battlefields did not match their romanticized concept of war. Photographers such as Mathew Brady brought the realities of warfare home by depicting bloated, bullet riddled bodies and scenes of carnage that literally scarred the land. Antietam marked the day that the public saw the inglorious war dead, and they reacted with repulsion and 'terrible fascination. ${ }^{126}$ For the people who went to view the battles, they experienced the horror of live warfare, not just the aftermath. For example, at the Battle of Bull Run, nearby Washington politicians and their families brought picnic lunches, hoping to watch the Union troops "lick the 'rebs,"' but were caught in the turmoil when Union forces retreated. ${ }^{127}$ Regardless of the risks, viewing parties and civilians continued to be common features on the battlefield.

In order to deal with the logistical issues that civilians created, commanders restricted access by denying passes. On November 19, 1861 the Richmond Daily Dispatch reported on the scene at Manassas, noting, "Visitors...have been pouring in by hundreds and have met with a poor reception. A general order has been issued permitting no civilians to pass the infantry pickets, unless by a special pass... It is now a poor place for those who have no business with the army." Restrictions were intended to keep the public safe, but civilian attendees came regardless. The chaos at the Seven Days Battle was testament to how the public's curiosity could interfere with military affairs and endanger them. A private recorded his experience in the Seven Days Battle for the Richmond Daily Dispatch on September 30, 1862, recalling:

\footnotetext{
${ }^{126}$ Dan Meinwald, "War," in Memento Mori: Death and Photography in Nineteenth Century America, part 3, http://vv.arts.ucla.edu/terminals/meinwald/meinwald3.html

${ }^{127}$ David J Eicher, The Longest Night: A Military History of the Civil War (New York : Simon \& Schuster, 2001), 98 .
} 
Scores of riderless, terrified horses dashing in every direction; thick-flying bullets singing by, admonishing of danger; every minute a man struck down; wagons and ambulances and cannon blockading the way; wounded men limping, and groaning, and bleeding amid the throng; officers and civilians denouncing, and reasoning, and entreating, and being insensibly borne along with the mass.

Civilians posed a logistical risk to troops that needed the ability to retreat quickly, but no wider concerns were addressed about sightseers than their potential for interference, because a nineteenth century familiarity with viewing death existed. The “terrible fascination" noted earlier was rooted in this familiarity and justified women's presence on the battlefield. It was customary practice to attend hangings and other public executions because they were treated as social events. Stuart Banner, author of The Death Penalty: an American History argues that people enjoyed attending such events for numerous reasons, but one was age-old, the thrill of watching violent death. ${ }^{128}$ Viewing death was also literally translated into photography. The daguerreotype process was frequently employed to produce a portrait style image of dead relatives, and at the advent of photography, war images were widely distributed. ${ }^{129}$ Additionally, the natural mortality rate in the first half of the nineteenth century was high, and life expectancy was low. This meant that people were exposed to death much more frequently from a young age, forcing death to become an integral and expected component of life. ${ }^{130}$ Death surrounded women, and as the good death dictated, an intrinsic part was being able to watch your loved one die. Women used this practice, as well as the societal acceptance of

\footnotetext{
${ }^{128}$ Stuart Banner, The Death Penalty: An American History (Cambridge: Harvard University Press, 2002), 161.

${ }^{129}$ Dan Meinwald, "The Body," in Memento Mori: Death and Photography in Nineteenth Century America, part 2, http://vv.arts.ucla.edu/terminals/meinwald/meinwald3.html

${ }^{130}$ Michael R. Haines, Lee A. Craig and Thomas Weiss, "The Short and the Dead: Nutrition, Mortality and the “Antebellum Puzzle" in the United States," Journal of Economic History 63 (2003): 386-387.
} 
watching death, as a means to justify their presence in the masculine sphere of battle.

Morbid curiosity and a tradition of viewing death certainly reinforced women's decision to form viewing parties, but patriotism played a central role as well. Septima Collis noted that the women of the Van Buren party came down from Washington to witness the Battle of Petersburg and to be the first Union women in Richmond; they wanted to stake their claim as central players in the political climate. The Washington politicians were more straightforward in their patriotic zeal; they wanted to see their soldiers "lick the rebs." Because women, by the very nature of their femininity, were denied access to the battlefield, as well as to the outward masculine expression of patriotism through enlistment, they physically inserted themselves into the sphere through viewing parties. Women couldn't step onto the battlefield as soldiers, but they could demonstrate their patriotism by showing support from the sidelines, a role that was traditionally theirs.

Some of the female sightseers assumed their traditional roles when watching from the sidelines. Under the Cult of True Womanhood, women often acted as the moral and religious authority in their homes, and were perceived as the moderating force for mankind as a whole. As a result, when women were not able to enter the battlefield as protectors, they stayed on the sidelines to pray for the safety of their relatives and the soldiers. When the war began at Fort Sumter, Mary Chestnut recorded the frenzied fear of the women on top of Charleston's rooftops. Chestnut astutely noted the differences between men and women's prescribed roles in the nineteenth century, noting that women prayed while men cursed: 
There was a sound of stir all over the house, pattering of feet in the corridors. All seemed hurrying one way. I put on my double-gown and a shawl and went, too. It was to the housetop. The shells were bursting. In the dark I heard a man say, "Waste of ammunition." I knew my husband was rowing about in a boat somewhere in that dark bay, and that the shells were roofing it over, bursting toward the fort. ... The regular roar of the cannon, there it was. And who could tell what each volley accomplished of death and destruction? The women were wild there on the housetop. Prayers came from the women and imprecations from the men. ${ }^{131}$

The women who came to the battlefield to watch and pray were assuming their natural roles as caretaker. Because they were limited in what they could do physically for the men on the field, they asserted their religious domain by praying for them. The battle at Fort Sumter was famously captured in art form, where the scene of women on the rooftops of Charleston depicted women in various states of distress, watchfulness and prayer, capturing the perception of women's private domestic sphere against the backdrop of men's violent public sphere. ${ }^{132}$

In the newspaper accounts of viewing parties, or "sightseers," it is telling that journalists do not claim that women were crossing a social barrier by watching death, particularly since the death they were witnessing was so graphic. Instead, they focus on the logistical issues created by women flooding the battlefields. This suggests that women were able to either consciously, or more likely unconsciously, capitalize on the collective practice of socializing death as a means to assert their presence on the battlefield. Moreover, the journalists assume that women were patriotic beings who wanted to see their side win a good fight, reinforcing the justification of patriotism. For women who were writing privately, they reiterated their roles of caretaker and religious

\footnotetext{
${ }^{131}$ Mary Boykin Chestnut, A Diary from Dixie (Chapel Hill: University of North Carolina at Chapel Hill), 35-36.

132 "Life in Civil War America," last modified March 3, 2011, http://www.nps.gov/history/history/online_books/civil_war_series/4/sec1.htm
} 
authority while watching a battle, indicating that they were still adhering to traditional gender roles.

Many of the sightseers were also "relic gatherers," a phrase used by the New York Times to describe parties that scoured the battlefields and camps for mementos. Relic gatherers would search the sites for bullets, clothing, guns, and so on, from dead soldiers as keepsakes. In other circumstances, relic gatherers were not looking for souvenirs, but desperately searching for vital necessities. Southern women used the camps to gather provisions as resources began to dwindle in the South, and the sites became critical sources of supplies. For many women of the South, curiosity and necessity compelled them into the camps and battlefields, placing an importance on the sites that was based on a need to connect to the war, or the war's effect on the home front.

After each battle, sightseers would descend on battlefields to retrieve objects that held special significance. On July 15, 1863, while Union soldiers went to the task of burying their dead and protecting the battle site at Gettysburg, a New York Times correspondent recorded the influx of people, noting "the battlefield is visited daily by thousands of people from all sections of the country." Many came to retrieve bodies, but more came out of curiosity. The reporter went on to add that "Thousands of dollars worth of guns and other military valuables are carried away by them from the field..." Military relics were the most obvious items collected because they provided a tangible link between the gatherer and the war. Confederates were aware of the magnitude of the war and its significance to American history, so they placed a high value on the objects that represented their revolutionary struggle.

We know that women were part of the civilian mass that descended on Gettysburg 
because the article later notes their presence, but for other battle fields women were there for a more simple reason; they made up the largest contingent of civilians. Conscriptions eventually took all able bodied males, leaving women, children and the elderly as the only remaining civilians on the home front. Men became such a commodity that Julia Johnson Fisher noted, "Everything that can hold a gun must go, and many would like to flee." ${ }^{133}$ By the war's conclusion, even male children were drafted into Confederate regiments because of the South's severe population disadvantage, coupled with high casualty rates, disease and desertion. ${ }^{134}$

At the end of the war, the New York Times reported again on relic gatherers when describing the scene of Johnston's surrender, on May 8, 1865. They reported the destruction of Mr. Bennett's house, where the agreement was reached, stating:

The unpretending wayside cottage, owned and occupied by Mr. Bennett, where Sherman and Johnston met to arrange the terms of surrender, is suffering at the hands of relic gatherers. The table on which the memoranda were written has been cut into fragments, and is in the hands of soldiers. The house is being carried off piece-meal. After the cottage the fence and trees will go, and in due time there will be an excavation to mark the spot where the disappearing Bennet [sic] cottage now stands.

Unlike the Gettysburg account this article criticizes relic gatherers because Confederates were taking the objects and not Union civilians. However, the journalist does not indicate that the practice was unusual, or even new. ${ }^{135}$ This is because a long tradition of relic gathering existed in America. Curio cabinets and natural history museums were accepted modes of viewing history and provided a tangible link between

\footnotetext{
${ }^{133}$ Julia Johnson Fisher, Julia Johnson Fisher Journal, 1864 (Chapel Hill: University of North Carolina, 1999), 5.

${ }^{134}$ In April of 1862 the draft, or conscription, was set for all white men between the ages of 18-35, but due to manpower shortages in 1863, the age was extended to men between 17-50. By 1865 the Confederacy was even conscripting slaves, see http://www.pbs.org/newshour/extra/teachers/lessonplans/socialstudies/timeline\%20of\%20of\%20conscripti on.pdf

${ }^{135}$ North Carolina Historic Sites, "Bennett Place," http://www.nchistoricsites.org/bennett/main.htm.
} 
the holder or viewer and the artifact. ${ }^{136}$ Items found on the battlefield provided a link between women and the important cultural events surrounding them, particularly during a time when women were shut out of the national discourse.

In the South, gathering these items took on a different connotation for women who relied on scavenged items for their survival. Women were hardest hit by shortages because they had to provide for their own families as well as for nearby troops and enemy combatants who demanded goods or simply stole. The situation was exasperated by the fact that crop and supply shortages were rampant in the South. ${ }^{137}$ Dolly Lunt Burge's diary provides a detailed example of the hardship she and her daughter endured when Sherman marched through Washington, GA on their way to the sea. Union troops devastated her supplies of food, conscripted her slaves and burnt her outhouses as part of the "total warfare" policy. She figured that they had stolen and destroyed approximately $\$ 35,000$ dollars worth, leaving her destitute. ${ }^{138}$ Eliza Francis Andrews on the other hand, recorded her patriotic joy at feeding the nearby Confederate troops since they had served the cause she loved so dear. However, Andrews repeatedly noted that her enthusiasm did

\footnotetext{
${ }^{136}$ Please see the following works that detail the emerging fields of curiosity, science, and classification: Amy R. W. Meyers and Margaret Beck Pritchard, ed. Empire's Nature: Mark Catesby's New World Vision (Chapel Hill: UNC Press, 1998), Susan Scott Parrish, American Curiosity: Cultures of Natural History in the Colonial British Atlantic World (Chapel Hill: University of North Carolina Press, 2006), James Delbourgo, A Most Amazing Scene of Wonders: Electricity and Enlightenment in Early America (Harvard UP, 2006), James Delbourgo, "Slavery in the Cabinet of Curiosities: Hans Sloane's Atlantic World," http://www.britishmuseum.org/pdf/delbourgo\%20essay.pdf, and D. Graham Burnett, Trying Leviathan: The Nineteenth-Century New York Court Case That Put the Whale on Trial and Challenged the Order of Nature (Princeton: Princeton University Press, 2007).

${ }^{137}$ Ashby, The Valley Campaigns, 73: "We were left to the invasion of the enemy and felt the apprehension that an enemy's presence is sure to create. Many of our people had shipped their most valuable horses, cattle, and other personal property within the Confederate lines, only keeping at home such stock as was needed for farming purposes. Stores and business houses were closed, but our farmers went on cultivating their crops with as much diligence as conditions would permit; for at this stage of the war we did not know what effect an invading army would have upon the lives and property of our people..."

${ }^{138}$ Dolly Lunt Barge, A Woman's Wartime Journal: an Account of the Passage over Georgia's Plantation of Sherman's Army on the March to the Sea, as Recorded in the Diary of Dolly Sumner Lunt (Mrs. Thomas Burge) (1918, repr., Chapel Hill: University of North Carolina Press, 1996), 20-29.
} 
not diminish the fact that supplies were very low and the troops were in great numbers, which overtaxed their ability to feed themselves. ${ }^{139}$

It was in this climate of necessity that Thomas Ashby recorded the importance of the camps to nearby populations, writing; "As soon as the camp was evacuated a number of men, women, and children, - colored and white, - went to the site of the camp to pick up all the old plunder and discarded articles left by the soldiers... It was not uncommon for the Federal troops to leave much valuable truck, such as hard tack, old clothes, blankets, boxes, and not infrequently old guns and pistols." ${ }^{140}$ Many of these items became incredibly scarce as the war took its toll on the Confederacy, so women took advantage of camps which were better supplied than civilians. The camps could be a valuable source of livelihood for women, but the battlefields were even more profitable. The Richmond Daily Dispatch reported on July 25, 1864 that local communities earned food from recovering military objects on the battlefield:

We noticed...six cars loaded with arms, knapsacks, cartridge boxes, sabres, \&c, together with a large lot of pig lead, the spoils of the battle fields of Wilderness and Spotsylvania. The balls are collected on the battlefield by the people living in the vicinity, brought to an established depot, and melted into pigs.... As lead is at this time in demand, it will be very acceptable... In return for lead and arms, he issues to the people corn meal and flour. There are many poor families in this neighborhood who have been despoiled by the Yankees of all they have, and this is of great assistance to them, as provisions are more important to them than money.

Due to the harsh wartime conditions in the South that affected women of every class, foraging became a necessary facet of survival. According to Faust, in North Carolina alone, up to $40 \%$ of women received governmental support and inefficient supply systems prohibited food from circulating throughout the South. Faust goes one

\footnotetext{
${ }^{139}$ Eliza Francis Andrews, The War-Time Diary of a Georgia Girl, 1864-1865 (1908, repr., Chapel Hill, University of North Carolina Press, 1997).

${ }^{140}$ Ashby, The Valley Campaigns, 111.
} 
step further and argues that scarcity produced factionalism in the South and ultimately explains why the Confederacy lost. ${ }^{141}$ It was not just necessity, but duty that led women to forage. Domesticity, as part of the Cult of True Womanhood, required that women provide for the needs of their families, and this became an extension of that role.

Ultimately, the negative economic realities of the South were another gateway for women to enter the masculine sphere of camp and battlefield.

Death was the central theme behind many women's decision to go to camp or the battlefield. The disintegration of burial practices became a deep concern for many women, but only the most resourceful were willing to travel alone to recover the remains so dear to them. These women were ardent believers in the sanctity of the corpse, a fact that proved itself when they were willing to look in mass graves, amongst decomposing bodies with little hope of identifying their relative. Their journey was not easy, either getting there or hauling a corpse back, and often times they had scant information about the whereabouts to begin with, but these women were able to traverse the battlefield and camp because they were reaffirming the idea of how death should be conducted and ensuring a good death.

Viewing parties were more nuanced than simple entertainment, even though that was certainly a component. Watching death had a long history in American culture; executions were commonly billed as public forums, and as Stuart Banner argued, watching violent death was an age old thrill. Additionally, viewing death became widespread and desensitized as the carnage of battles was heavily photographed under the new technology. Many women simply wanted to watch their rebels beat the Union forces,

${ }^{141}$ Drew Gilpin Faust, "The Civil War Homefront," in Rally on the High Ground: the National Park Service Symposium on the Civil War, ed., Robert K. Sutton, online book, http://www.cr.nps.gov/history/online_books/rthg/fore.htm. 
particularly since they framed their ideals in the language of tyranny and viewed themselves as patriots. Others understood that they were denied the ability to publicly express their patriotism in the way that soldiers could, so they inserted themselves onto the battlefield as a public display of their patriotism. Women also acted out on their role of religious authority and caretaker in the home to pray for the safety of their loved ones as they watched from the sidelines, reinforcing their adherence to the Cult of True Womanhood.

Relic gatherers were a niche of women who acted on the long standing tradition of collecting objects. Curio cabinets and museums were accepted modes of viewing history and allowed the viewer to physically connect with the past. Many of the relic gatherers were cognizant of the significance of the Civil War and they sought military objects that could provide a tangible link. However, many women of the South were forced to collect items for their innate value as resources, not for their symbolic worth. The war hit the Southern economy hard, and in an agrarian society that depended on manual labor women who were left without the aid of their husbands struggled to survive. When troops camped nearby or a battle took place, the sites acted as a feeding ground for supplies. Southern women of all classes were hit financially by the inflation of the Confederate currency, so respectable women, as well as the poor utilized these sites. These women were simply enacting their role of caretaker and assuring that their families were provided for, and as such, they did not receive social scrutiny.

On the surface, all of these women were crossing a social barrier by entering the camp and field, but death was the central theme that mitigated their presence there. The battlefield itself was a scene of death, often acting as a cemetery, and was part of the 
masculine sphere reserved for soldiers. It was the setting where masculinity and femininity were separated; men were able to assert their patriotism by giving the ultimate sacrifice while women watched from the sidelines. As stated in chapter 2, women did act as soldiers, but this was not a role sanctioned by the government because the idea of a violent nature was reserved for men alone. Women were to be nurturers and caretakers, so their presence on the battlefield ran counter to ideas of women's proper spheres. However, women were able to gain access to this restricted sphere without sacrificing their respectability by using long standing social traditions such as what constituted a good death, communal viewing of death, and the importance of relic gathering to the understanding of significant events or for necessity. 


\section{CHAPTER 4 NURSES IN THE CAMPS AND HOSPITALS}

As the Civil War broke out, the role of women came into question, and many in the public saw their responsibility as passive supporters of active troops. Women quickly rejected this restraint and mobilized on an unprecedented scale. Thousands of women in the North and South formed aid societies, sanitary commissions, and raised money for their cause. More than just knitting socks or making jams, women also became interested in the political landscape and began to talk politics and debate the future of their country. These ventures into public discourse pushed many women one step further, into seeking out positions that provided more than passive home front assistance, but allowed them to experience a tangible impact on the outcome of the war. The female soldiers discussed earlier were an extreme example of women who were willing to depart from traditional gender roles, but most women did not go that far, instead settling on a middle ground that did not break social barriers. A large segment of Southern women saw their natural roles as caregivers in the home as an opportunity to serve the Confederacy outside of it, producing a force of women who signed up to become nurses. I have included nurses in this paper because the sphere of camp can be expanded to include the hospital. At its core, the camp was essentially a large concentration of soldiers living in temporary housing away from the general public, and existing under the purview of the military and government. Established hospitals, field hospitals, and makeshift civilian hospitals fall under this definition because they were extensions of camp that housed concentrations of 
convalescing soldiers, not the general public, fell under the authority of the military and were frequently encompassed by traditional camps.

Both sides of the conflict were under the assumption that the war would last a mere six months and be done, but once the reality struck that it was going to be a bloody protracted war, the Confederate government began to assemble an organized and large scale hospital system, initially concentrated around Richmond. The newly formed government was also responding to rumors that soldiers were being poorly cared for amidst dingy and squalid "hospital" tents. In the North, General McClellan recognized his responsibility for the care of soldiers and at the urging of the U.S Sanitary Commission, Surgeon General William Hammond and Medical Director David Letterman he devised the ambulance corps and field hospital system. ${ }^{142}$ Phoebe Yates Pember penned a memoir after the war about her experiences nursing, recalling that the Confederate Congress was "desirous of remedying omissions" and passed a law that allowed matrons to be appointed to hospital staffs in the hopes of providing better care. However, despite the opening of the field to women, very few respectable ladies signed up to become nurses. It was primarily the working classes and uneducated women that offered their services in droves. ${ }^{143}$

Wealthy Southern women were not interested in becoming nurses because it challenged their very respectability and had the potential to tarnish the attributes that made them ladies. Pember articulated the fears of the upper class when she wrote, "the natural idea that such a life would be injurious to delicacy and refinement of a lady-that

\footnotetext{
${ }^{142}$ Dale C. Smith, "Military Medical History: The American Civil War," OAH Magazine of History 19 (2005): 18.

${ }^{143}$ Phoebe Yates Pember, A Southern Woman's Story: Life in Confederate Richmond, ed. By Bell I. Wiley (Atlanta: Morningstar Books, 1959), 15-16.
} 
her nature would become deteriorated and her sensibilities blunted, was rather appalling."

Pember was speaking from experience as a member of the Virginia gentry, accustomed to all the luxuries that accompanied wealth, the idea of becoming a laborer on par with slaves and working women was unpalatable. A strict hierarchy existed throughout the South, and women of means were very careful to make sure that their actions were never perceived as labor, but as charity. Additionally, Southern gentlemen were vocal in their opposition to their wives, sisters and daughters joining the nursing corps and going to camps or hospitals. When Ada W. Bacot, a wealthy young lady from Charleston, sought to help the Confederacy by nursing, her father spoke with Dr. John Chisolm of South Carolina College to dissuade her from going because "that twas scarcely a place for a lady. ${ }^{144}$ In response to the widening opposition, an unidentified Confederate agent wrote to the Richmond Daily Dispatch appealing the need for women to donate their nursing skills. On August 6, 1861 the following plea was published:

Having observed in the Richmond Dispatch that nurses are not wanted, I deem it proper to state, from practical experience, that ladies of strong health and good judgment are very much required as directors for cooking, cleansing and nursing, as without this necessary care there is little prospect of relief to our many sick and sadly-suffering soldiers. That high-toned gentlemen should object for ladies to witness the disgusting signs of illarranged hospitals, is not to be wondered at, though they would gladly have these things remedied. Officers wish their men to be taken care of, and during a short stay in camp life, I have had more applications for assistance from Surgeons of other regiments, who have not nurses, than it is possible to attend to. A great request is made for Scripture readers, or Chaplains. A Chaplain, nurse, and good baker, are three essentials to every camp.

Gentlemen were concerned about women being exposed to the "disgusting signs

of ill-arranged hospitals," but the scenes on the battlefields and in hospitals were

\footnotetext{
${ }^{144}$ Ada W. Bacot, A Confederate Nurse: the Diary of Ada W. Bacot, ed. Jean V. Berlin (Columbia: University of South Carolina Press, 1994), 56.
} 
gruesome for all visitors, including men. ${ }^{145}$ Kate Cummings recorded her first exposure to nursing in her diary during the outbreak the war, recalling; "I sat up all night, bathing the men's wounds, and giving them water...the foul air from this mass of human beings at first made me giddy and sick... and when we give the men anything kneel, in blood and water..."146 Hannah Ropes recalled a patient who had been shot through the shoulder and how she had to change his dressing three times a day by "cutting the shirt open on the shoulder, down the front and taking out the left sleeve." ${ }^{\prime 47}$ Pember graphically recorded the wounds she encountered, including a patient who had been shot twice in the face, "knocking out the teeth...the swollen lips turned out, and the mouth filled with blood, matter, fragments of teeth from amidst all of which the maggots in countless numbers swarmed and writhed...” These recollections of a day's work reveal that nursing was arduous, unsettling, and unsanitary, aspects that did not conform to the traditional lifestyle of privileged Southern women.

Cheryl Wells further articulates this concept in her article "Battle Time: Gender, Modernity and Confederate Hospitals," arguing that archetypal Southern womanhood meant "modesty, domesticity, purity, delicacy, refinement, gentility, and subordination," all attributes that nursing as a profession opposed. ${ }^{148}$ Most importantly, it meant exposure to male bodies, which was unacceptable for women trying to live by the Cult of True Womanhood. Phoebe Pember recalled a woman who initially made several attempts to become a nurse, but upon arrival at Chimborazo, stated that she "was not going anywhere

\footnotetext{
${ }^{145}$ Jane E. Schultz, "The Inhospitable Hospital: Gender and Professionalism in Civil War Medicine," Signs 17 (1992): 366.

${ }^{146}$ Kate Cummings, Kate: the Journal of a Confederate Nurse, ed. Richard Barksdale Harwell (Baton Rouge: Louisiana State University Press, 1959), 15.

${ }^{147}$ Hannah Ropes, The Diary and Letters of Hannah Ropes, ed. John R. Brumgardt (Knoxville: University of Tennessee Press, 1980), 58.

${ }^{148}$ Cheryl A. Wells, "Battle Time: Gender, Modernity and Confederate Hospitals," Journal of Social History, 35 (2001): 409.
} 
in a place where a man sat up on his bed in a shirt..."149 This was naturally impossible because the wards were filled with men considered half naked by nineteenth century standards. The fact that the line between propriety and duty were blurred in the hospitals made it a moral penumbra, and many in Southern society were simply uncomfortable with this fact.

A social stigma attached to nursing for reasons similar to those encountered by unattached women who entered the camps; sexual vulnerability. Many young nurses who attempted to join the nursing corps were perceived as husband hunters and sirens. Kate Cummings wrote a disparaging note in her journal about a young widow "black sheep" who claimed "that she had never enjoyed herself so much as she had since she had been here; that, when she left home, she was told that she must try to catch a beau-and she had succeeded." The party was horrified that a woman could think of romance and claim to enjoy herself amongst such suffering. Surgeon General Hammond of the Union army received a letter where the writer was concerned about female nurses "exciting their (soldiers) animal passions." ${ }^{150}$ In the North, Dorothea Dix only allowed old, unattractive, and practical women of stout constitution to work as nurses in her hospitals. Even Dr. Esther Hill Hawks, a formally trained and matriculated doctor, was not allowed to join Dix's ranks because of her youth and beauty. ${ }^{151}$ Due to these underlying concerns about male and female sexuality, Southern newspapers called for "discreet" women to apply to nursing positions and instructed other women to provide medical supplies from home. ${ }^{152}$

\footnotetext{
${ }^{149}$ Pember, A Southern Woman's Story, 33.

${ }^{150}$ Jane E. Schultz, Women at the Front: Hospital Workers in Civil War America (Chapel Hill: University of North Carolina Press, 2004), 124.

${ }^{151}$ Esther Hill Hawks, A Woman Doctor's Civil War, ed. Gerald Schwartz (Columbia: University of South Carolina Press, 1989), 10. Hawks was an ardent abolitionist who worked as a volunteer nurse in black regiments, living in camp with them in Florida, the Sea Islands and Charleston.

152 "Our Sick and Wounded Soldiers in Virginia," The Carolina Watchman, July 14, 1862.
} 
When Phoebe Pember discovered that a new matron had set up her quarters amongst the wounded soldiers at Chimborazo Hospital, she wrote, "no woman was allowed to stay in the wards, for obvious reasons." ${ }^{, 153}$ Unmarried women residing in camps and hospitals posed a serious concern for society, and respectable women were forced to contend with this reality if they sought positions as nurses.

Another group that made explicit their concerns with women acting as nurses was surgeons. Nursing was not synonymous with femininity, or even professionalized, until after the war, and the majority of "nurses" were male soldiers. ${ }^{154}$ In the camps male soldiers acted as ambulance drivers and assistants to surgeons; in army hospitals convalescing soldiers were put to work in the wards doing remedial labor and surgeons had stewards that acted as pharmacists, general managers and clerks. ${ }^{155}$ As the war broke out there was little precedent for women acting as nurses outside of their homes, with the exception of Florence Nightingale, famed nurse of the Crimean War, who eventually inspired thousands of women. Gender expectations of the nineteenth century restricted women's mobility outside of the home and severely limited the spheres that women were allowed to enter; which naturally included areas where women could be exposed to naked, wounded men.

Surgeons however, were not concerned with the lack of modesty that nursing required, but with the difficulties that women imposed on the spartan accommodations, and the threat of women usurping or ignoring their authority. When Pember made her

\footnotetext{
${ }^{153}$ Pember, A Southern Woman's Story, 21.

${ }^{154}$ Frank McGregor, Dearest Susie: A Civil War Infantryman's Letters to His Sweetheart, ed. Carl E Hatch, (New York: Exposition Press, 1967), 40-41; After the battle of Vicksburg Frank McGregor became ill with "typhoid malaria" and was taken to the Van Buren Hospital where he remained from April-October of 1863, during which time he remained in the hospital as a convalescing nurse, also see "The City During the Battle" Carolina Watchman June 9, 1862 notice asking for "nurses, both male and female are wanted." ${ }^{155}$ Carol Cranmer Green, Chimborazo: The Confederacy's Largest Hospital (Knoxville: University of Tennessee Press, 2004), 41-42.
} 
first appearance at Chimborazo Hospital, she was part of the first wave of matrons sought out by the Confederate government to help restructure and provide better care to wounded and ill soldiers. These women were not well regarded, and she recalled that the new laws mandating their inclusion, even if they were ranked below stewards and paid nominally, invoked fears of "petticoat government." ${ }^{\text {"156 Kate Cummings experienced }}$ similar opposition on her way to Mobile to tend to the wounded of Ketchum's Battery; she noted that "it seems that the surgeons entertain great prejudice against admitting ladies into the hospital in the capacity of nurses." Dr. Caldwell, presiding surgeon of that hospital, was so adamant in his beliefs that he would not even allow women to distribute milk and bouquets, or to visit with patients. ${ }^{157}$

The issue of nursing was a complicated subject during the war because women were placed in the center of an evolving discourse on the roles of women in the public sphere. On one side, necessity demanded public involvement, but husbands and surgeons were uncomfortable with respectable women working in hospitals, breaking the longstanding paternalistic order. Drew Faust argues in "Altars of Sacrifice: Confederate Women and the Narratives of War" that as the war commenced women were told messages about how to behave and sacrifice in ways that aligned with their traditional functions. This translated into propaganda that labeled women as the defenders of the moral order, forcing their husbands, sons and brothers to behave as courageous soldier's. ${ }^{158}$ The Magnolia Weekly: A Southern Home Journal, was one such periodical produced during the short-lived Confederacy that pushed this message, calling for women to realize

\footnotetext{
${ }^{156}$ Pember, A Southern Woman's Story, 17.

${ }^{157}$ Cummings, Confederate Nurse, 12.

${ }^{158}$ Drew Gilpin Faust, "Altars of Sacrifice: Confederate Women and the Narratives of War," Journal of American History 76 (1990): 1206-1209.
} 
their moral nature so that men might go out and fight courageously. ${ }^{159}$ Women rebelled against such passivity, instead developing aid societies and seeking out positions as nurses, or becoming female soldiers. In response to the growing need for women to play an active role, as well as the mounting necessities of wartime, the media began to redefine the stigma of women working outside their homes. Journalists and the Confederate government began to call for women nurses, but they stipulated that it was only acceptable so long as women did not subvert the authority of the male surgeons. ${ }^{160}$ Despite opposition women became nurses largely because disapproval was not uniform. Many in the public saw nursing as a natural extension of women's roles, and hailed women's efforts to aid the troops. Just a few short months after the war began on June 27, 1861, The Carolina Watchman celebrated the women of Richmond who were volunteering their services as nurses, noting "this is truly a womanly movement." Additionally, necessity forced many to implore women to think of their patriotic duty. The fledgling Confederate government was not prepared for war, and its troops were even less so; in response, women provided the clothing, food and medicine that troops required, as well as a significant portion of the manpower that was needed to staff the new hospitals, particularly as the death toll rose. Necessity and patriotism went hand in hand and were a successful tactic to convince women to do their duty. The Richmond Daily Dispatch used this approach on April 23, 1861 when it admired the "patriotic women" of Richmond, noting, "May their noble example be imitated by all the daughters of Virginia!"

\footnotetext{
${ }^{159}$ Kathleen L. Endres and Therese L. Lueck, Women's Periodicals in the United States: Consumer Magazines (Westpotr: Greenwood Press, 1995), 205-206.

${ }^{160}$ Faust, "Altars of Sacrifice," 1215-1216.
} 
Thousands of women became nurses, but the minority were women of the upper class, and that number went down even further for women who voluntarily traveled with the troops as regimental nurses. Dr. Esther Hill Hawks is the only elite woman who chronicled her experiences as a 'nurse' traveling with black Union troops, so unfortunately, we will never know the exact motivations of respectable Southern women who took a step further and entered field hospitals. However, they were likely similar to those of women who acted as nurses in permanent hospitals. Hawk's experience was atypical because she acted as a doctor for black troops since surgeons in white armies did not accept her as an equal and she felt that black regiments would be more receptive to her ministrations. The number of women who served directly in the camps as professional nurses is extremely low, but they were there. The Richmond Daily Dispatch recorded a woman who volunteered to travel with the troops on May 21, 1862, writing:

A noble spirited young lady--Miss Leona Neville--has volunteered her aid and services as nurse to the ranks of the Monroe Rifles, attached to Col. Hunt's Regiment. The ceremony of her formal reception in this sturdy band of soldiers took place at their headquarters on Julia street last evening, and was witnessed by a large number of ladies and gentlemen. She was presented to Lieut. Hinckly of the Rifles, by their commander, Capt. Benjamin, in a very excellent and impressive speech, and the Lieut. formally presented her to the soldiers, who welcomed her with all the deference and respect which careful, soldierly training can instill into the military man. The young lady had of her own free will chosen to brave the dangers of the battlefield, and must indeed be nerved by the fortitude of a - we like to have said, "hero"--well, "hero" be it, for she looked the hero, with her nicely-fitting black alpaca uniform.

However, respectable Southern women were exposed to camp hospitals much

more frequently than their Northern counterparts because battles were predominantly fought on Southern soil, and many women offered their services spontaneously. Additionally, many women had to provide their homes to friendly and enemy troops as makeshift hospitals, as their homes became part of camp. These women were never 
formally counted, but thousands of women opened their homes to troops and camps as nearby battles took their tolls.

The reason many Southern women were more difficult to recruit was because they demanded autonomy and authority, elements that surgeons did not permit. Wells argues in "Battle Time" that Confederate surgeons attempted to control matrons by regulating their schedules, but this was met with limited success. ${ }^{161}$ The majority of nurses in the South were poor white women who desperately needed the income and were accustomed to the labor, as well as loaned out slaves. There are no exact figures for how many Confederate women worked as nurses, or for those that doubled as cooks, laundresses and nurses because any records burnt with Richmond. In the black regiments, nurses were typically black women and wives of the soldiers who did various jobs. However, modern speculation figures in the tens of thousands, including the many women who worked as nurses on a limited basis when a battle raged near their homes.

Part of the reason that women felt particularly equipped to nurse was because they were considered natural caregivers. Schultz notes that nursing was a "manifestation of female identity and a domestic responsibility." 162 In the antebellum period women were idealized as self-sacrificing, caring and nurturing, attributes necessary to raise children and serve their husbands. Pember articulates this by writing that women took an "active part in all that came within their sphere," and felt "a passion of interest in every man in the gray uniform...doubly anxious to give comfort and assistance to the sick and wounded." For Pember, womanhood was defined by an innate desire to care for men. ${ }^{163}$ A significant part of motherhood encompassed the health of the family, and many women

\footnotetext{
${ }^{161}$ Wells, "Battle Time," 411-412.

162 Schultz, Women at the Front, 20.

${ }^{163}$ Pember, A Southern Woman's Story, 16.
} 
acted as nurses to their families and neighbors during illness. For women of the ruling class, nursing responsibilities extended to slaves as well. It was not formal training that made women nurses, but an idea that inherent characteristics tied to femininity were sufficient to provide medical care. Dorothea Dix did not look for women to staff Union hospitals who had a history of hospital work, but for women of sound moral character.

Southern women responded to opposition and changing attitudes towards women's public involvement in a myriad of ways. The most common explanation women gave for their decision was patriotic fervor, or duty. Southerners rarely identified their 'peculiar institution' as the cause for secession and war, but instead framed it as an idealistic right to autonomy and independence from federal tyranny, similar language used in the American Revolution. Many Southerners believed their cause to be divinely appointed, and as the Confederacy seceded, women became vocal propagators of the call to duty. When reflecting on the death of a friend's son, Kate Cummings articulated popular sentiment of their sacred, semi-religious cause, stating "may they find consolation in the thought that he died a martyr's death; was offered up a sacrifice upon the altar of his country." ${ }^{, 64}$ Ada Bacot exclaimed in her diary upon learning that her trip to Virginia to work as a nurse had been realized, "Oh! that I may be able to perform my duty." 165 With the movement being couched in such patriotic language, many women felt that they needed to contribute in a tangible way. However, women were denied the ultimate patriotic self-expression, the sacrifice of their lives on the battlefield, which left them resentful of gender and socially imposed worthlessness. ${ }^{166}$ In response, many

\footnotetext{
${ }^{164}$ Cummings, Confederate Nurse, 9.

165 Bacot, A Confederate Nurse, 52.

${ }^{166}$ Faust, "Altars of Sacrifice," 1206.
} 
formed aid societies and provided vital necessities, and thousands others joined the ranks of nurses to help those who were able to give the ultimate sacrifice.

Once in the hospitals and camps, women further justified their decision by separating themselves from women of the lower class. Pember was upset to learn that very few ladies had responded to the Confederate Congress' call for matrons to be appointed to hospitals, but instead received an influx of "uneducated women, hardly above the laboring classes." ${ }^{167}$ Even though nursing paid very little, women quickly became desperate for income as their husbands, sons and brothers were no longer around to provide financial stability. Additionally, the war took a heavy toll on the resources of the South and women were forced to work in places that met their basic needs of food and shelter, as the hospitals did.

Elite women separated themselves from poor working women by refusing to take a salary and become a hired hand, or laborer. Hannah Ropes was particularly sensitive to the motivations of the nurses that surrounded her and often disparaged the common working women. On July 6, 1862 Ropes wrote to her sister Alice about an influx of a hundred nurses, pointedly remarking, "Miss Stevenson is a true disciple of Him who thought it not beneath Him to gird with a towel and wash His disciple's feet. Miss Kendall, her friend, is lovely, endowed with the same spirit. The other nurses are common women who reckon their pay and have eyes open to see if we fare better than they." ${ }^{, 68}$ Ropes clearly distinguished between women who were motivated by patriotic and Christian virtue to help out their cause and the women who were forced to nurse for less altruistic motives. According to Ropes, there was a hierarchy of women, and those

\footnotetext{
${ }^{167}$ Pember, A Southern Woman's Story, 16.

${ }^{168}$ Ropes, Letters of Hannah Ropes, 107.
} 
with the financial means to "work" without pay were at the top. The divide between these women became so great that Ropes noted in a letter to her brother that when their mother died three of the nurses she loved dearly were devoted to her, and that "they wanted me to tell her friends that no hired hands ever touched her during her sickness." ${ }^{169}$

For other matrons, such as Pember, working class women represented a threat to order. Many of the working women did not abide by the social constructs that respectable women did, and they regularly subverted her authority by becoming drunk on the whisky rations. Whisky was regularly prescribed to convalescing soldiers for a myriad of ailments, but drinking was also a popular pastime in resource-strapped Richmond, so the hospital supply quickly became an incredibly valuable commodity. This fact forced Pember to continuously engage in a "whisky war," where she attempted to guard the scarce resource from patients, soldiers, surgeons and nurses. After numerous attempts to protect the whisky, Pember sought out nurses who would help her cause. She debated whether to use "ladies of education and position," or the "common class" who might be more amenable to authority. She chose the latter, but her experiment failed and the working women quickly became so intoxicated and violent that they had to be removed by ambulance. ${ }^{170}$ While Pember's story tells that common women were not acquiescent to authority, it also reveals that the women of position were not either. They were perceived as autonomous and above authority, a stance they cleverly utilized to separate themselves from the common nurses. Respectable women used the themes of status, patriotism, and Christian virtue to create terms by which they were willing to enter the

\footnotetext{
${ }^{169}$ Ibid., 128.

${ }^{170}$ Pember, A Southern Woman's Story, 32-33.
} 
hospitals. These terms were vital because they created a hierarchy and distinction between women who worked for pay and those that did not.

Another mode that ladies used to separate themselves from paid nurses was to restrict the types of labor they would do. The Confederate government created a hierarchy for the head matrons that relegated the manual labor to assistants and nurses, allowing respectable women to act as managers. ${ }^{171}$ Frequently, plantation mistresses would loan out their slaves to work in the hospitals who were then assigned to the tasks they usually performed for their owners. When Pember first arrived at Chimborazo the hierarchy had not been established and she found herself doing all the cooking; when the head surgeon discovered this error, he assigned a team of female nurses and soldiers to do the work. More important to many women was the stipulation that they be able to utilize their literacy to write letters. They enjoyed writing letters to sweethearts, mothers and often wrote final condolences that assured family members their loved one had died a "good death."172 For many matrons, it was imperative that they be allowed to work directly with the soldiers, so they sought out positions where they could visit with them, pray together, write letters and wipe the sweat from their brows. ${ }^{173}$ These tasks paralleled those of the home, so most women felt comfortable assuming the role of nurturing mother.

During the war the press came to celebrate nurses, and afterwards, their deeds were immortalized by authors such as Frank Moore, but the path to nursing was not always smooth. There was a disconnect between the public propaganda put out by the Confederacy, who were concerned with improving conditions in the hospitals as well as

\footnotetext{
${ }^{171}$ Cumming, Confederate Nurse, xiv-xv, 45.

172 Pember, A Southern Woman's Story, 18, 26; Cumming, Confederate Nurse, 20-21.

${ }^{173}$ Pember, A Southern Woman's Story, xiv.
} 
providing a patriotic outlet for repressed women, and the reality of how the hospital challenged women's respectability. The hospitals were filled with men from every socioeconomic category, which meant that the potential for sexual encounters, exposure to naked men and disease, and hostility from surgeons, were daily realities for nurses. The confluence of these factors created a sphere that many women were unwilling to enter. In a paternalistic society, the women who were willing to disregard such threats were often stopped by their relatives, who refused to expose their families to criticism. Even if the hospitals were models of propriety, social hierarchies were deeply reinforced in Southern society. Women of the upper classes rarely took employment, and since nursing was typically a mixture of assorted responsibilities that generally fell to the working class, including cooking, cleaning, changing linens and dressings, they did not want to be associated with laborers. For many women, they were blocked by bureaucratic matters. In the North, Dix's stringent requirements eliminated thousands of young, single, and attractive women from nursing. In the South, many surgeons were threatened by a potential "petticoat government," and refused to allow women into their hospitals, or treated them poorly once they arrived.

Regardless of the obstacles, thousands of women did become nurses. More however became impromptu nurses as battles were waged near their communities, but these women never intended to commit long-term. For the majority of Southern women, nursing was not an option, either for compulsory reasons such familial obligations, but more likely because they were not comfortable leaving their domestic sphere. Most women stayed at home and provided home front assistance. For those that were able to become nurses, they created barriers that allowed them to retain their respectability. They 
created hierarchies based on altruistic motivations, refused to do remedial labor, and refused pay. Despite such precautions, the few diarists who recorded their nursing experiences still endured ridicule back home and had to respond defensively. These nurses existed in a tumultuous time, not just politically, but socially, where gender barriers were being pushed and expanded, resulting in personal and public backlash against their positions as nurses. However, Confederate nurses ultimately created new avenues of acceptability that were reflected in post-war celebrations of their efforts and helped pave the way for the professionalization of nursing. 


\section{CONCLUSION}

Women's experiences during the Civil War were affected by a clash between the burgeoning women's rights movement and the Cult of True Womanhood, by which Southern women were continuously influenced. The mobilization of women created a new sense of autonomy and engagement in the public sphere, but women were also simultaneously expected to retain the traditional ideals of femininity, respectability and domesticity. Giselle Roberts discusses this phenomenon among Southern women, arguing that "Confederate belles redefined their place in society out of patriotism and

necessity, yet struggled to relinquish their antebellum role for the wartime ideal."174 These expectations were communicated to women by their mothers who had lived in the antebellum era, as well as by male relatives, potential suitors, sermons, and through the political realm. Women were continuously inundated with literary, verbal, and print images about their role in society as wives and mothers, imposing a core identity on them that did not collapse simply because the war produced new canons. Women astutely recognized the dichotomy between their prescribed roles as respectable women and the demands of the Confederacy that asked women to become more engaged in the public sphere, utilizing this expanding definition of womanhood as an excuse to venture into camp while still remaining within the Cult of True Womanhood.

\footnotetext{
174 Giselle Roberts, "The Confederate Belle: The Belle Ideal, Patriotic Womanhood, and Wartime Reality in
} Louisiana and Mississippi, 1861-1865," The Journal of the Louisiana Historical Association 43 (2002): 192. 
Women were not only imposed upon to remain within the Cult of True Womanhood, but they deeply identified with it, assuming its attributes of piousness, purity, submissiveness and domesticity. The label of respectability was vitally important to women because it determined their prospects in life. If women had the ultimate goal of marriage, which was their aim so that they did not have to remain dependent upon their parents for life, then their respectability improved those chances. It also defined their place in society, particularly since the South still relied heavily on a class system and produced social hierarchies. For the nurses, female soldiers, young women and bereaved women who entered camps, their respectability was their central concern when articulating their motives.

Unlike the camp followers of the Revolution who came out of necessity, women of the Civil War had to create more nuanced reasons for why they entered the camps because they were so far removed from appropriate spheres for women. The Civil War was billed as an exclusively masculine war, framed in the terminology of brother versus brother and galvanized over three percent of the male population. The camps themselves were defined by the soldiers who lived in them, creating a masculine space that was both public and corrupted, the antithesis of the private female sphere. Soldiers of every socioeconomic background were represented, and in the South, where class still acted as a determining factor to respectability; this posed a challenge for women who wanted access to men of equaled status. Men from every class were complicit however in making the camp a place that retained many of the attributes of a brothel. Men were living away from the limitations of their families and exposed to the ever increasing availability of 
prostitutes. But more than just rampant prostitution, the camps were dirty, crude and filled with language considered vulgar by nineteenth century standards.

The battlefields and hospitals were similarly hostile to women. The battlefield was the defining tenant of a masculine war because it was a public place where men expressed their inherently violent natures. It also acted as the fulfillment of political discourse. As the war became inevitable, politicians and the male public demanded that the dispute between Southern and Northern states could only be resolved through warfare. The public was caught up in this revolutionary fervor, but only men were allowed to voice their patriotism with the most significant sacrifice, their lives. The disparity between men and women's roles during the war was depicted as women watched from the sidelines as men waged war.

While the hospitals were somewhat more welcoming to women, the conditions within them, and the expectations of nurses about their duties, did not conform to women's expectations. The newly established hospital system fell under the responsibility of the military and housed only convalescing soldiers, which made them an extension of the camp. As such, they were filled with male soldiers who languished in all states of distress and undress. Many soldiers were recovering from horrific wounds inflicted by brutal modern artillery, as well as crippling diseases passed in the camps, which meant that most nurses witnessed gruesome scenes never before experienced in their homes. Women were also open to accusations of impropriety and labeled workers, professional labor being something respectable women simply did not perform.

With camp, battlefield and hospital conditions being largely inhospitable to women who were accustomed to more refined circumstances, women were forced to 
create separate spheres in the camp that conformed to their ideas of acceptability. For each group of women examined, this took on a different from. Some of the women physically separated themselves while others created a narrative that conformed to the ideals of womanhood even though they had publicly disregarded gender roles. For others, they relied on long standing social traditions, but all ultimately attempted to conform to the Cult of True Womanhood even when their decision outwardly appeared to break gender barriers.

Young, wealthy, unmarried Southern women were opportunistic when using the camps as a place to meet potential suitors and enjoy entertainment. Women of the upper classes did not have occupations and were therefore accustomed to a schedule that included significant time for socializing. The mobilization of troops meant that young women were exposed to unprecedented numbers of young men that were available for amusement, and they wanted to capitalize on this. In response to the societal expectation of marriage, women also used the camps as a venue for meeting unmarried men. Before the war, women were limited to males from their local communities, but the war drastically expanded their opportunities without having to travel long distances. The soldiers were willing participants because the young women provided a distraction from the rigorous and monotonous camp life, with many soldiers noting that the women reminded them of home. But reputable women could not simply walk into camp and meet men; they would have been mistaken for prostitutes and opened themselves up to accusations of impropriety. Instead, women used the pretext of visiting relatives to gain entrance. 
In the nineteenth century, when young men and women spent time together as friends or for courting, chaperones were commonly used. However, chaperoning did not have to be a formal arrangement but could simply be a group of friends who acted as selfpolicers. More commonly though, women used their male relatives as chaperones when socializing because they assured propriety and provided access to eligible men of equal status. When Emma Holmes entered the camps, she noted that she was visiting her brothers and cousins, but was always considering their friends as potential suitors. Soldiers in the South were fortunate that they were more likely to be stationed near family than Union soldiers, which meant that their female relatives had greater opportunity to visit in camp. Visiting relatives was as common in the nineteenth century as it is today, so women were able to easily move into the camp with this purpose, and their male relatives acted as their entry point into a sphere that was otherwise inhospitable to respectable women.

The soldiers acted as complicit chaperones and hosts, creating distinct spheres in the camps for their female relatives and companions. The men were cognizant of the risks women took when entering camp, so they helped shield them from accusations of indecency. Women were careful to limit their interactions within the camp population to relatives, family friends, and officers, essentially men of equal status. When they did activities that required them to mix with the camp population, they accompanied a male relative. For their part, the men created separate spaces when women were invited into camp to enjoy entertainment, delineating specific places that were acceptable. Women visiting their relatives often visited in their tents, and took meals there to assure that they did not interact with the outer populace. Inside the tent, the relatives and friends would 
talk and play familiar games, recreating traditional social calls. When officers wanted to host dances, the soldiers created dance halls out of camp materials, confining the women to a specific space that was separated from the outside camp. These dances mimicked customary social events and provided an outlet for soldiers enduring the rigors of camp life.

Many young women experienced a newfound sense of autonomy because they were left behind on the home front without the guiding authority of their fathers and brothers. Mothers however, continued to instill the values of the Cult of True Womanhood, so women frequently regulated themselves during the war years. The ability to enter the camps for entertainment and romance was tempered by the desire to remain respectable, leading women to cleverly utilize their relatives as a way to gain entry. They were not willing to risk their reputations so they played on traditional rules of courting and entertainment, but transferred them from the parlor to the camp. Even though the camps were rife with disease, drunkenness, prostitution and men from every socioeconomic background, respectable women were ultimately able to traverse this domain without censure by creating separate spheres that conformed to the Cult of True Womanhood.

Female soldiers had to be shrewder than the young women who entered the camps for entertainment because they were breaking every prescribed gender role by cross dressing and assuming the characteristics of men. As Sarah Wakeman reveals, female soldiers were often from the middle and lower classes, in large part because they needed the wages, but they were as concerned about their reputations as women of the upper classes were once they were discovered. This demonstrates that women from all classes 
adhered to the Cult of True Womanhood to one degree or another, but women of the upper classes were simply more able to because they had the luxury of existing solely as wives and mothers in the domestic sphere. Women on the bottom rung, or those behaving outside the realms of womanhood were labeled unrespectable, so it is interesting that female soldiers were able to wield the Cult of True Womanhood in on itself to gain a level of respectability never granted to them previously.

As discussed in Chapter two, we will never know each woman's separate impetus, whether it was monetary, patriotic, a reaction to gender repression, or the one they gave, that they followed a husband or lover into battle. It is unlikely however that all the women who were discovered had such similar motivations, or when they were not interviewed directly, that the journalists imposed a similar story on the women. It is more likely that women wanted to mold a response for the public that allowed their actions to be viewed in a light that was understood as traditional womanly behavior. If they had simply stated that they dressed as man, lived amongst unrelated men and fought in battles for the sake of money or glory, many in the public would have been appalled and likely been suspicious that they were actually prostitutes. Then these women would have had to go home and face the censure of their family and friends. Instead, they came up with an excuse that did the exact opposite; it ironically allowed them to remain women while still dressed as men.

Women were expected to be nurturing wives and mothers, so the public understood when a woman stated that she was so concerned for the safety of her husband that she followed him into battle as his protector. It was certainly an extreme measure, but not out of the realm of womanhood. It was important for the female soldier to note 
that she was married because this authorized her living amongst the general camp population as long as she was accompanied by her husband, assuring propriety. The female soldiers were also aided by the public themselves who indulged in a romantic literary tradition that venerated the female warrior motif based off Joan of Arc. Even though many female soldiers were discovered after being arrested for drunkenness or rowdiness, many still wanted to believe that they were heroines who fit this romanticized mold. Female soldiers were able to attain unprecedented levels of autonomy as men, but once they were ousted in the camp, hospital, prison, or as a POW, they were able to use the media to spin a story about their motivations that placed them right back in the Cult of True Womanhood.

Part of the Cult of True Womanhood for women was acting as the religious mainstay in the family, upholding important traditions and beliefs. To a larger extent, women as a whole were regarded as the defenders of the moral and religious order, keeping men conscious of their faith while existing in the corrupted public sphere. When the traditions surrounding death were reduced and then discarded due to the increasingly massive mortality rate during the war, women became insistent that society not disregard these sacred practices. A fervent adherence to the good death led many women to enter the camps in search of their relative's remains so that they might conduct as much of the burial process as possible. The good death placed high emphasis on the body, and women did not want their loved ones to remain in unmarked, mass graves. Women often had to travel alone to do so, which was regarded as problematic because women rarely traversed the public domain, but they were willing to disregard these criticisms so that they could assure a good death, upholding their sacred duty. 
Death led other women into camp as well, and a contingent of them used their religious authority to pray over men in battle, providing a measure of control. The women of Charleston watched from the rooftops as Fort Sumter was bombarded and many of them prayed for the safety of their relatives because they were not able to physically insert themselves into the battle or offer tangible aid. Their prayers also reinforced the role of peacemaker and nurturer that women were expected to be. Men existed in the corrupted public sphere and had violence in their natures which was contrasted by women's desire for peace. Other women formed viewing parties because they were denied the opportunity to fight themselves, and their presence acted as an outward sign of their patriotism. Viewing death as an entertainment form was reinforced by a long standing tradition of watching violent death in public executions, and women were exempt from censure for doing so during the war because their curiosity was emblematic of the wider national occurrence.

Republican Motherhood taught that women were to raise civically minded and patriotic children, but not to engage in politics themselves, a tenet that became impossible as the war heightened nationalistic fervor. Women relic-gatherers attempted to connect to the significance of the war by collecting objects that symbolized the military struggle for independence. Their enthusiasm for the Confederate cause led them to want a tangible connection from its early beginnings, so women took items that they felt had special significance. A long American practice of collecting curiosity pieces made relicgathering an accepted act, which further fueled the practice throughout the North and South. 
However, for many women deeply affected by the war-produced scarcity, they used the battlefields and camps to collect objects for survival. Conditions in the South were extremely poor because the blockade created shortages, there was widespread crop failure, and European markets closed to cotton imports. The Confederate government responded by allowing women to collect military valuables in exchange for food and supplies, and other women simply collected valuables they needed. Part of domesticity required that women attend to the needs of their families, ensuring that they were fed, clothed and educated. When inflation got so bad in the South, the wages that men earned as soldiers were not sufficient and many men deserted on the pleas of their wives at home. But when the men were at the front, women were expected to act as head of household and fulfill the basic needs of their families, which gathering items from the battlefields allowed them to do. Even though women were exposed to horrific scenes on the battlefields, rotting corpses and wounded and dying men, their need to provide for their families allowed them to enter a space that was considered wholly unsuitable for women while retaining their respectability.

Nurses received the greatest public and private backlash about their decision to enter the hospitals as the topic was part of a wider national debate on women's roles in the war. On the domestic front, men did not want their female relatives exposed to censure for living amongst men and being witness to naked, wounded, male flesh. Hospitals in the nineteenth century were not sanitary and rife with communicable diseases, which men also did not want women exposed to. The Confederacy on the other hand desperately needed women to reform the hospitals and provide the nurturing nature that accompanied womanhood, so they appealed to women's sense of duty. Many 
respectable women were eventually swayed by the pleas of the Confederacy, but the women themselves worried about being affixed with the stigma of laborer. Elite women did not work or hold professions, only women of the lower classes worked outside of the home for wages. Even with altruistic motives, respectable women felt it necessary to stipulate their terms of service once they agreed to act as nurses.

In response to their core identities as the elite, respectable women removed themselves from an association with the working class by creating hierarchies in the hospitals. They first did this by refusing wages, differentiating themselves based off altruistic motives and not monetary gain. And second, they stipulated the kind of labor they would perform. They wanted to take on roles that reflected the nurturing characteristics of womanhood, so they insisted that they get to spend time with soldiers reading to them, writing their letters, wiping their brows, and so on. They were insistent that they not have to do the manual labor required of the paid nurses such as changing sheets and bedpans, cooking and cleaning. They also often acted in managerial positions as the matrons of the hospitals, placing them at the top of the social and work hierarchy.

These acts also served to reinforce women's place in the Cult of True Womanhood, even when their surroundings and professionalization normally would have excluded them. Military nurses were traditionally men because they had to work with convalescing male soldiers, but women were the nurses in their homes because the role of caretaker was naturally assigned to women. When the Confederacy needed to reform the squalid hospital system, they assumed that women were a natural fit and would improve conditions since that was their responsibility at home. Due to this, nursing became a position that was somewhat excluded from the stigma of labor because it utilized 
women's natural roles. The women were also integral in defining and maintaining their own respectability by specifying the work they performed. They only did jobs that reflected their nurturing temperament and refused to do hard manual labor, maintaining their status as elite women. They also claimed philanthropic motives, refusing wages, which reiterated their position of piety in the family and in society. Many respectable women did receive criticism from their family and friends, but the opening up of the public sphere to women allowed them to vocalize their patriotism and sense of duty through tangible aid to the cause.

The experiences of women varied widely throughout the war, but all were impacted by the shifting ideas of women's ability to exist in the public sphere and make significant contributions to the war effort. While the progress did not last past the end of the war, which is evidenced by the fact that women's suffrage was not achieved for another fifty five years, women were still granted greater degrees of autonomy that would propel the movement forward. Nina Silber aptly explains in Daughters of the Union that women were granted this autonomy because men were away at war, leaving women behind to act as head of household, forcing women to walk a fine line between selfsufficiency and domesticity. ${ }^{175}$ While Silber discusses Northern women, this argument applies to the Southern female camp followers as well. It was because of their expanded autonomy and newfound authority that they were able to enter the camps, but the camps were still not considered appropriate spheres for women. In response, women relied on their adherence to the Cult of True Womanhood to maintain the traditional ideals of womanhood, even when their presence in camp appeared to contradict those ideals.

\footnotetext{
${ }^{175}$ Nina Silber, Daughters of the Union: Northern Women Fight the Civil War (Cambridge: Harvard University Press, 2005), 3-10.
} 
For each camp follower, adhering to the Cult of True Womanhood took on a different form. Some women created separate spheres in the camps in order to socialize, while others fabricated stories for the press that played on their womanly roles as protectors; but all were ultimately committed to maintaining, or giving the illusion of abiding by, traditional gender roles. The idea of women's proper private sphere had been stridently reinforced during the antebellum years and women did not dispel this identity simply because the war was providing new opportunities to experience the public sphere. Instead, Southern women reverted back to their traditional roles during the Reconstruction years while authors such as Frank Moore used literature to nudge them on their way. Ultimately, women were able to enter the camps because they did so at a time when the definition of womanhood was broadening, but more importantly, because the women themselves were careful to verbalize and reassure society that they were still abiding by the Cult of True Womanhood, even if by an expanded definition. 


\section{BIBLIOGRAPHY}

\section{Introduction}

Anthony, Susan B., Elizabeth Cady Stanton, and Matilda Joslyn Gage. History of Woman Suffrage Vol. 2. Rochester: Charles Mann, 1887.

Casler, John O. Four Years in the Stonewall Brigade. Dayton: Morningside Bookshop, 1971.

Clinton, Catherine. Public Women and the Confederacy. Milwaukie: Marquette University Press, 1995.

Clinton, Catherine. The Other Civil War: American Women in the Nineteenth Century. New York: Hill and Wang, 1999.

Engerman, Stanley L. "A Reconsideration of Southern Economic Growth, 1770-1860." Agricultural History 49 (1975): 334-361.

Forbes, Ella. African American Women during the Civil War. New York, Garland Publishing, 1998.

Graf, Stephen Mercedes. On the Field of Mercy: Women Medical Volunteers from the Civil War to the First World War. Amherst: Humanity Books, 2010.

Harper, Judith E. Women During the Civil War: an Encyclopedia. New York: Routledge, 2007.

Kelley, Duren F. The War Letters of Duren F. Kelley 1862-1865. Edited by Richard S. Offenberg and Robert Rue Parsonage. New York: Pageant Press, 1967.

Leonard, Elizabeth. Yankee Women: Gender Battles in the Civil War. New York: W.W. Norton, 1995.

Lowry, Thomas. The Story the Soldiers Wouldn't Tell: Sex in the Civil War. Mechanicsburg: Stackpole Books, 1994.

Mayer, Holly A. Belonging to the Army: Camp Followers and Community during the American Revolution. Columbia: University of South Carolina Press, 1999.

McPherson, James. The Illustrated Battle Cry of Freedom. Oxford: Oxford University Press, 2003.

McPherson, James. Battle Cry of Freedom: the Civil War Era. New York: Oxford University Press, 1988.

Moore, Frank. Women of the War: their Heroism and Self-Sacrifice. Hartford: S.S. Scranton \& Co., 1866. 
Nelson, Michael. "Writing During Wartime.” Journal of American Studies 29 (2001): 4368.

Perry, Harriet and Theophilus Perry. Widows by the Thousand: The Civil War Letters of Theophilus and Harriet Perry 1862-1864. Edited by M. Jane Johansson. Fayetteville: University of Arkansas Press, 2000.

Sacher, John. "The Ladies are Moving Everywhere": Louisiana Women and Antebellum Politics." Louisiana History: the Journal of the Louisiana Historical Association 42 (2001): 439-447.

Silber, Nina. Daughters of the Union: Northern Women Fight the Civil War. Cambridge: Harvard University Press, 2005.

Taylor, Susie King. Reminiscences of My Life in Camp: An African American Woman's Civil War Memoir. Athens: University of Georgia Press, 2006.

Varon, Elizabeth. "Tippecanoe and the Ladies, Too: White Women and Antebellum Politics in Virginia.” Journal of American History 82 (1995): 494-521.

Welter, Barbara. "The Cult of True Womanhood 1820-1860.” American Quarterly 18 (1966): 151-174.

\section{Chapter 1: Unmarried Women in Camp}

Anderson, Patricia J. When Passion Reigned: Sex and the Victorians. New York: Basic Books, 1995.

Andrews, Eliza Francis. The War-Time Journal of a Georgia Girl 1864-1865. Edited by Spencer Bidwell King Jr. Atlanta: Cherokee Publishing Company, 1976.

Boyd, Belle. Belle Boyd in Camp and Prison. Baton Rouge: Louisiana University Press, 1998.

Buck, Lucy Rebecca. Sad Earth, Sweet Heaven: The Diary of Lucy Rebecca Buck. Edited by Dr. William P. Buck. Birmingham: The Cornerstone Publisher, 1973.

Buck, Lucy Rebecca. Shadows on my Heart: the Civil War Diary of Lucy Rebecca Buck of Virginia. Edited by Elizabeth R. Bauer. Athens: University of Georgia Press, 1997.

Casler, John O. Four Years in the Stonewall Brigade. Dayton: Morningside Bookshop, 1971.

Cogan, Frances B. All American Girl: The Ideal of Real Womanhood in Mid-NineteenthCentury America. Athens: The University of Georgia Press, 1989. 
Collis, Septima Maria Levy. A Woman's War Record, 1861-1865. Chapel Hill, University of North Carolina at Chapel Hill, 1997.

Condra, Jill and Anita Stampler. Clothing through American History: The Civil War through the Gilded Age, 1861-1899. Santa Barbara: Greenwood Press, 2011.

Faust, Drew. Mothers of Invention: Women of the Slaveholding South in the American Civil War. Chapel Hill: University of North Carolina Press, 1996.

Gates, Paul W. Agriculture and the Civil War. Edited by Allan Nevins. New York: Alfered A. Knoph, 1965.

Giesberg, Judith Ann. Army at Home: Women and the Civil War on the Northern Home Front. Chapel Hill: University of North Carolina Press, 2009.

Holmes, Emma. The Diary of Miss Emma Holmes 1861-1866. Edited by John F. Marszalek. Baton Rouge: Louisiana State University Press, 1979.

LeConte, Emma. Emma LeConte Diary, 1864-1865. Chapel Hill: University of North Carolina at Chapel Hill, 1998.

Mason, Michael. The Making of Victorian Sexual Attitudes. New York: Oxford University Press, 1994.

McPherson and William Cooper Jr., 201-227. Columbia: University of South Carolina Press, 1998.

Mintz, S. "Casualties and Costs of the Civil War." Digital History, http://www.digitalhistory.uh.edu.

Ott, Victoria E. Confederate Daughters: Coming of Age during the Civil War. Carbondale: Southern Illinois University Press, 2008.

Perry, Harriet and Theophilus Perry. Widows by the Thousand: The Civil War Letters of Theophilus and Harriet Perry 1862-1864. Edited by M. Jane Johansson. Fayetteville: University of Arkansas Press, 2000.

Roark, James L. "Behind the Lines: Confederate Economy and Society." In Writing the Civil War, edited by James

Turner, Jeffery S. Dating and Sexuality in America, a Reference Handbook. Santa Barbara: ABC-Clio, 2003.

Theriot, Nancy. Mothers and Daughters in Nineteenth-Century America: The Biosocial Construction of Femininity. Lexington: University of Kentucky Press, 1996.

Thomas, Emory M. The Confederacy as a Revolutionary Experience. Englewood: Prentice-Hall, 1971. 
Williamson, Alice “Alice Williamson Diary,” Special Collections Library, Duke University, http://scriptorium.lib.duke.edu/williamson/

\section{Chapter 2: Female Soldiers in Camp}

“A Female Soldier.” The Abingdon Virginian. January 30, 1863.

“A Female Soldier-Her Sad History.” Big Blue Union. March 26, 1864.

“A Romantic Story.” The Smoky Hill and Republican Union, June 6, 1863.

Bahs, Amy. "The Feminized Civil War: Gender, Northern Popular Literature, and the Memory of the War, 1861-1900." The Journal of American History 85 (1999): 14611494.

Blaetz, Robin. Visions of the Maid: Joan of Arc in American Film and Culture. Charlottesville: University Press of Virginia, 2001.

Blanton, DeAnne and Laura Cook. They Fought like Demons. Baton Rouge: Louisiana State University Press, 2002.

"Book Review-They Fought Like Demons, Women Soldiers in the Civil War by DeAnne Blanton and Lauren M. Cook" in The Smithsonian Associates Civil War E-Mail

Newsletter, Volume 5, Number 6, http://civilwarstudies.org/articles/Vol_5/deamons.shtm.

Burgess, Lauren Cook, ed. An Uncommon Soldier: The Civil war Letters of Sarah Rosetta Wakeman, alias Private Lyons Wakeman 153 ${ }^{\text {rd }}$, New York State Volunteers. Pasadena: The Minerva Center, 1994.

Eggleston, George Cary. “Twenty-One.” In Southern Soldier Stories. New York: Macmillan Company, 1898.

Faust, Drew Gilpin. Mothers of Invention: Women of the Slaveholding South in the American Civil War. Chapel Hill: University of North Carolina Press, 1996.

Fields, Jill. "Erotic Modesty: (Ad)dressing Female Sexuality and Propriety in Open and Closed Drawers, USA, 1800-1930." Gender and Sexuality 3 (2002): 492-515.

Hall, Richard C. Women on the Civil War Battlefront. Lawrence: University Press Kansas, 2006.

Leonard, Elizabeth D. All the Daring of the Soldier. New York: W. W. Norton and Company, 1999.

Livermore, Mary A. My Story of the War. New York: Arno Press, 1972. 
Moore, Frank. Women of the War: Their Heroism and Self-Sacrifice. Hartford: S.S. Scranton \& Co., 1866.

Pember, Phoebe Yates. A Southern Woman's Story: Life in Confederate Richmond. Edited by Bell I. Wiley. Atlanta: Morningstar Books, 1959.

Rotman, Deborah L. "Separate Spheres? Beyond the Dichotomies of Domesticity," Current Anthropology 47 (2006): 666-674.

Ryan, Mary P. “Gender and Public Access.” In Habermas and the Public Sphere, ed. Craig Calhoun. Cambridge: The MIT Press, 1992.

Velazquez, Loretta. The Woman in Battle: A Narrative of the Exploits, Adventures and Travels of Madame Loreta Janeta Velazquez. Edited by C.J Worthington. New York: Arno Press, 1972.

Wall, Diana Di Zerega. "Sacred Dinners and Secular Teas: Constructing Domesticity in Mid-19th-Century New York." Historical Anthropology 25 (1991): 69-82.

Welter, Barbara. “The Cult of True Womanhood 1820-1860," American Quarterly 18 (1966): 151-174.

\section{Chapter 3: Death in the Camps and Battlefields}

“A Brave Woman.” New York Times. December 4, 1861.

Andrews, Eliza Francis. The War-Time Diary of a Georgia Girl, 1864-1865. Chapel Hill, University of North Carolina Press, 1997.

Ashby, Thomas A. The Valley Campaigns Being the Reminiscences of a NonCombatant While Between the Lines in the Shenandoah Valley During the War of the States. Chapel Hill, University of North Carolina at Chapel Hill, 1998.

Banner, Stuart. The Death Penalty: An American History. Cambridge: Harvard University Press, 2002.

Barge, Dolly Lunt. A Woman's Wartime Journal: an Account of the Passage over Georgia's Plantation of Sherman's Army on the March to the Sea, as Recorded in the Diary of Dolly Sumner Lunt (Mrs. Thomas Burge). Chapel Hill: University of North Carolina Press, 1996.

Bethell, Mary Jeffreys. Mary Jefferys Bethell Diary: January 1, 1861-December 1865. Chapel Hill: University of North Carolina, 2000.

Chestnut, Mary Boykin. A Diary from Dixie. Chapel Hill: University of North Carolina at Chapel Hill. 
Collis, Septima. A Woman's War Record 1861-1865. Chapel Hill: University of North Carolina at Chapel Hill.

Eicher, David J. The Longest Night: A Military History of the Civil War. New York : Simon \& Schuster, 2001.

Faust, Drew Gilpin. This Republic of Suffering: Death and the American Civil War. New York: Alfred A. Knopf, 2008.

Faust, Drew Gilpin. "The Civil War Homefront." In Rally on the High Ground: the National Park Service Symposium on the Civil War, ed., Robert K. Sutton, online book, http://www.cr.nps.gov/history/online_books/rthg/fore.htm.

Fisher, Julia Johnson. Julia Johnson Fisher Journal, 1864. Chapel Hill: University of North Carolina, 1999.

Haines, Michael R., Lee A. Craig and Thomas Weiss, "The Short and the Dead: Nutrition, Mortality and the "Antebellum Puzzle" in the United States," Journal of Economic History 63 (2003): 384-392.

Harrison, Constance Cary. Recollections: Grave and Gay. Chapel Hill: University of North Carolina at Chapel Hill, 1998.

Haskell, Frank Aretas. Battle of Gettysburg. New York: Harvard College Library, 1918. "Rebellion." New York Times, February 4, 1863.

Mayer, Robert G. Embalming: History, Theory and Practice. New York: McGraw-Hill Medical Publishing Division, 2006.

Meinwald, Dan. "War." In Memento Mori: Death and Photography in Nineteenth Century America Part 3, http://vv.arts.ucla.edu/terminals/meinwald/meinwald3.html

Meinwald, Dan. "The Body." In Memento Mori: Death and Photography in Nineteenth Century America Part 2, http://vv.arts.ucla.edu/terminals/meinwald/meinwald3.html

North Carolina Historic Sites, "Bennett Place,"

http://www.nchistoricsites.org/bennett/main.htm.

Smile, J. "Waiting for the Mail.” Richmond Daily Dispatch. August 24, 1861.

\section{Chapter 4: Nurses in the Camps and Hospitals}

Bacot, Ada W. A Confederate Nurse: the Diary of Ada W. Bacot. Edited by Jean V. Berlin. Columbia: University of South Carolina Press, 1994. 
Cummings, Kate. Kate: the Journal of a Confederate Nurse. Edited by Richard Barksdale Harwell. Baton Rouge: Louisiana State University Press, 1959.

Endres, Kathleen L. and Therese L. Lueck. Women's Periodicals in the United States: Consumer Magazines. Westport: Greenwood Press, 1995.

Faust, Drew Gilpin. "Altars of Sacrifice: Confederate Women and the Narratives of War.” Journal of American History 76 (1990): 1200-1228.

Green, Carol Cranmer. Chimborazo: The Confederacy's Largest Hospital. Knoxville: University of Tennessee Press, 2004.

Hawks, Esther Hill . A Woman Doctor's Civil War. Edited by Gerald Schwartz. Columbia: University of South Carolina Press, 1989.

McGregor, Frank. Dearest Susie: A Civil War Infantryman's Letters to His Sweetheart. Edited by Carl E Hatch. New York: Exposition Press, 1967.

“Our Sick and Wounded Soldiers in Virginia.” The Carolina Watchman. July 14, 1862.

Pember, Phoebe Yates. A southern Woman's Story: Life in Confederate Richmond, ed. By Bell I. Wiley. Atlanta: Morningstar Books, 1959.

Ropes, Hannah. The Diary and Letters of Hannah Ropes. Edited by John R. Brumgardt. Knoxville: University of Tennessee Press, 1980.

Schultz, Jane E. “The Inhospitable Hospital: Gender and Professionalism in Civil War Medicine." Signs 17 (1992): 363-392.

Schultz, Jane E. Women at the Front: Hospital Workers in Civil War America. Chapel Hill: University of North Carolina Press, 2004.

Smith, Dale C. "Military Medical History: The American Civil War," OAH Magazine of History 19 (2005): 17-19.

Wells, Cheryl A. "Battle Time: Gender, Modernity and Confederate Hospitals." Journal of Social History, 35 (2001): 409-428.

"The City During the Battle." Carolina Watchman June 9, 1862

\section{Conclusion}

Giselle Roberts, Giselle. "The Confederate Belle: The Belle Ideal, Patriotic Womanhood, and Wartime Reality in Louisiana and Mississippi, 1861-1865," The Journal of the Louisiana Historical Association 43 (2002): 189-212. 
Silber, Nina. Daughters of the Union: Northern Women Fight the Civil War. Cambridge: Harvard University Press, 2005. 